J. I. Federer and J.A. McEvers

Date Published: August 1990

Prepared for the Assistant Secretary for Conservation and Renewable Energy, office of Industrial Technologies ED $011200 \quad 0$

Prepared by the OAK RIDGE NATIONAL LABORATORY

Oak Ridge, Tennessee 37831-6285 operated by

MARTIN MARIETTA ENERGY SYSTEMS, INC.

for the

U.S. DEPARTMENT OF ENERGY

under Contract DE-AC05-840R21400 


\section{CONTENTS}

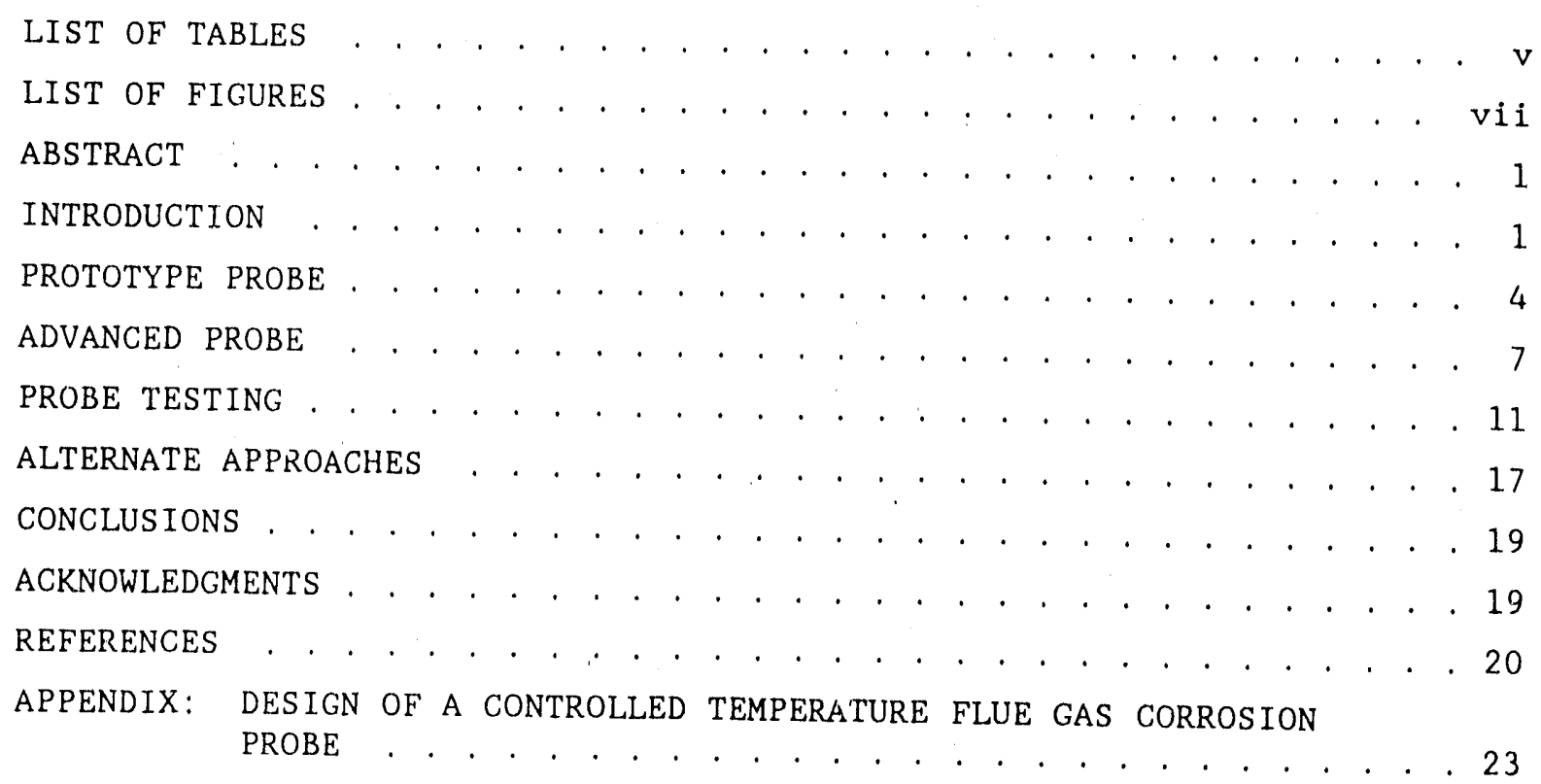




\section{LIST OF TABLES}

Table 1. Comparison of corrosion test methods . . . . . . . . . 3

Table 2. Dimensions and CTEs of oxide specimens . . . . . . . . 11 
Fig. 1. Schematic of corrosion probe . . . . . . . . . . . . . . 4

Fig. 2. Prototype probe being heated by internal gas combustion in the laboratory . . . . . . . . . . . . . . . . . . . . . . . . 6

Fig. 3. Schematic of advanced corrosion probe with specimens of different materials . . . . . . . . . . . . . . . . . . . . . . . 7

Fig. 4. Schematic of assembly of a specimen onto the SiC core tube

Fig. 5. Advanced probe before testing

Fig. 6. Prototype probe after exposure to coal combustion products . . . . . . . . . . . . . . . . . . . . . . . 13

Fig. 7. Results of a cooling test at a nominal furnace temperature of $400^{\circ} \mathrm{C}$. . . . . . . . . . . . . . . . . . . . 14

Fig. 8. Results of a heating test at a nominal furnace temperature of $400^{\circ} \mathrm{C}$. . . . . . . . . . . . . . . . . . . . . . 15

Fig. 9. Results of a cooling test at a nominal furnace temperature of $1000^{\circ} \mathrm{C}$. . . . . . . . . . . . . . . . . . . 16

Fig. 10. Results of a heating test at a nominal furnace

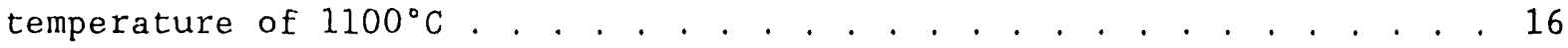




\title{
CONSTRUCTION AND TESTING OF A FLUE-GAS CORROSION PROBE*
}

\author{
J. I. Federer and J. A. MeEvers
}

\begin{abstract}
ABSTRAC'T
The selection of suitable materials for industrial, wasteheat-recovery systems requires assessment of corrosion of materials in various flue-gas environments. Such assessments involve exposing candidate materials to high-temperature flue gases and analyzing the effects of the exposure conditions. Because corrosion is related to flue-gas chemical composition and temperature, variations in temperature complicate the determination of corrosion rates and corrosion mechanisms. Conversely, a relatively constant temperature allows a more accurate determination of the effects of exposure conditions. For this reason, controlled-temperature flue-gas corrosion probes were constructed and tested for exposure tests of materials. A prototype probe consisted of a silicon carbide tube specimen, supporting hardware, and instrumentation for controlling temperature by internal heating and cooling. An advanced probe included other tubular specimens. Testing of the probes in an industrial-type furnace at a nominal flue-gas temperature of $1200^{\circ} \mathrm{C}$ revealed that temperature control was inadequate. The cooling mode imposed a substantial axialtemperature gradient on the specimens; while the heating mode + imposed a smaller gradient, the heating capacity was very limited. The probe, as currently designed, is not a costeffective method for obtaining corrosion data in hightemperature industrial-furnace flue gases. Other approaches are suggested, and details of construction and testing of a prototype probe and an advanced probe are presented.
\end{abstract}

\section{INTRODUCTION}

Metallic heat exchangers are used extensively to recover heat from flue gases of industrial furnaces. Typically, heat is transferred from the flue gases through a partition wall to air or steam. The preheated air can be used for combustion in the same furnace, thereby decreasing fuel use.

\footnotetext{
${ }^{*}$ Research sponsored by the Industrial Energy Efficiency Divisicr, office of Industrial Technologies, U.S. Department ö̈ Energy, under contract DE-AC05-840R21400 with Martin Marietta Energy Systems, Inc.
} 
The temperature of the metallic partition wall i.s 1 imited to about $850^{\circ} \mathrm{C}$ because of severe oxidation or other corrosion and loss of strength that occurs at higher temperatures. Preheated combustion air temperatures, therefore, range from 500 to $800^{\circ} \mathrm{C}$. A heat exchanger with ceramic tubes, providing the partition wall can tolerate much higher temperatures $\left(>1200^{\circ} \mathrm{C}\right)$, can produce combustion air preheated to higher temperatures $\left(1000\right.$ to $\left.1100^{\circ} \mathrm{C}\right)$, and, therefore, can save substantially more energy than a metallic heat exchanger.

The U.S. Department of Energy, Office of Industrial. Technologies [formerly office of Industrial Programs (DOE-OIP)], has conducted research and development of high-temperature, ceramic heat exchangers through industrial contractors in recent years. ${ }^{1,2} \mathrm{~A}$ common protlem in heatexchanger concepts is the durability of ceramic materials exposed to corrosive, high-temperature flue gases in certain industrial applications. Conventional exposure tests in industrial-furnace flue-gas streams have frequently been used to assess the corrosion behavior of candidate materials for critical components such as heat-exchanger tubes, headers, and structural members. ${ }^{3-6}$ These tests involve installing characterized specimens of various ceramic materials in a furnace, recovering th: specimens at a later date, and analyzing the specimens to determirie the extent of corrosion or other degradation. The disadvantages of this type of test include:

- Specimen temperature is not controlled and sometimes not we1l. known.

- Flue-gas temperature cycles frequently in some furnaces; therefore, specimen temperature also cycles.

- Corrosion data are based on a complicated temperature-time history.

- Corrosion rates for specific temperatures are not determined.

- The effect of temperature on corrosion rates is not determined.

- Extrapolation of data to other furnaces with different temperature-time histories is difficult.

- Stresses caused by atypical thermal cycling can cause additional degradation.

A possible solution to these problems is a ceramic corrosion probe with temperature-control capability provided by auxiliary heating and cooling. The probe would consist of one or more materials exposed to 
fluctuating temperatures in furnace flue gases. Auxiliary heating or cooling within the probe would allow control of the probe temperature within a wide range of flue-gas temperatures. Several probes could be operated simultaneously at temperatures of interest in a combustion environment. Either constant temperatures or selected variations representing a particular heat exchanger could be maintained. Knowledge of the temperature-time history would be useful in subsequent interpretation of corrosion results. The probe concept is not new; metallic corrosion and fouling probes have been widely used.7,8 Usually cylindrical pipes, they are cooled by air flowing through the bore with strategically located thermocouples to indicate temperatures. Because these probes were designed to operate below the flue-gas temperature, auxiliary heating was not required.

As shown in Table 1, disadvantages of a corrosion probe include the limited number of specimens and the cost per specimen relative to conventional exposure tests. Conventional exposure tests could still be used to screen the corrosion behavior of a large number of materials. Then, the

Table 1. Comparison of corrosion test methods

\begin{tabular}{lll}
\hline \multicolumn{1}{c}{ Criteria } & Conventional & Probe \\
\hline Materials per test & Many & Few \\
Cost per specimen & Low & Moderate \\
Temperature known & Maybe & Yes \\
$\begin{array}{l}\text { Temperature controlled } \\
\text { Temperature-time } \\
\text { history }\end{array}$ & No & Yes \\
$\begin{array}{l}\text { Corrosion rate at } \\
\text { temperature of } \\
\text { interest }\end{array}$ & Maybe & Simple \\
$\begin{array}{l}\text { Effect of tempera- } \\
\text { ture on corrosion } \\
\text { rate }\end{array}$ & No & Yes \\
$\begin{array}{l}\text { Data that can be } \\
\text { extrapolated }\end{array}$ & & Yes \\
$\begin{array}{l}\text { Furnace shutdown } \\
\text { required for } \\
\text { installation and } \\
\text { removal }\end{array}$ & Maybe & Yes \\
\hline
\end{tabular}


corrosion probe could be used to obtain pertinent data on the better materials. Table 1 indicates that probes would be advantageous in other respects, especially in determining corrosion rate at a particular temperature or as a function of temperature. The construction and testing of a prototype probe and an advanced probe ale described herein.

\section{PROTOTYPE PROBE}

Designed by using a computer model to evaluate the effects of size, cooling air-flow rate, heating capacity, and flue-gas temperature and massflow rate on the range of temperature control (see the Appendix), 9,10 a prototypo probe was constructed for testing in an industrial furnace. The probe consists of a tubular ceramic (SiC) specimen, a stainless steel end fixture, and instrumentation for controlling temperature (Fig. 1). Air

ORNL - DWG - $90-13906$

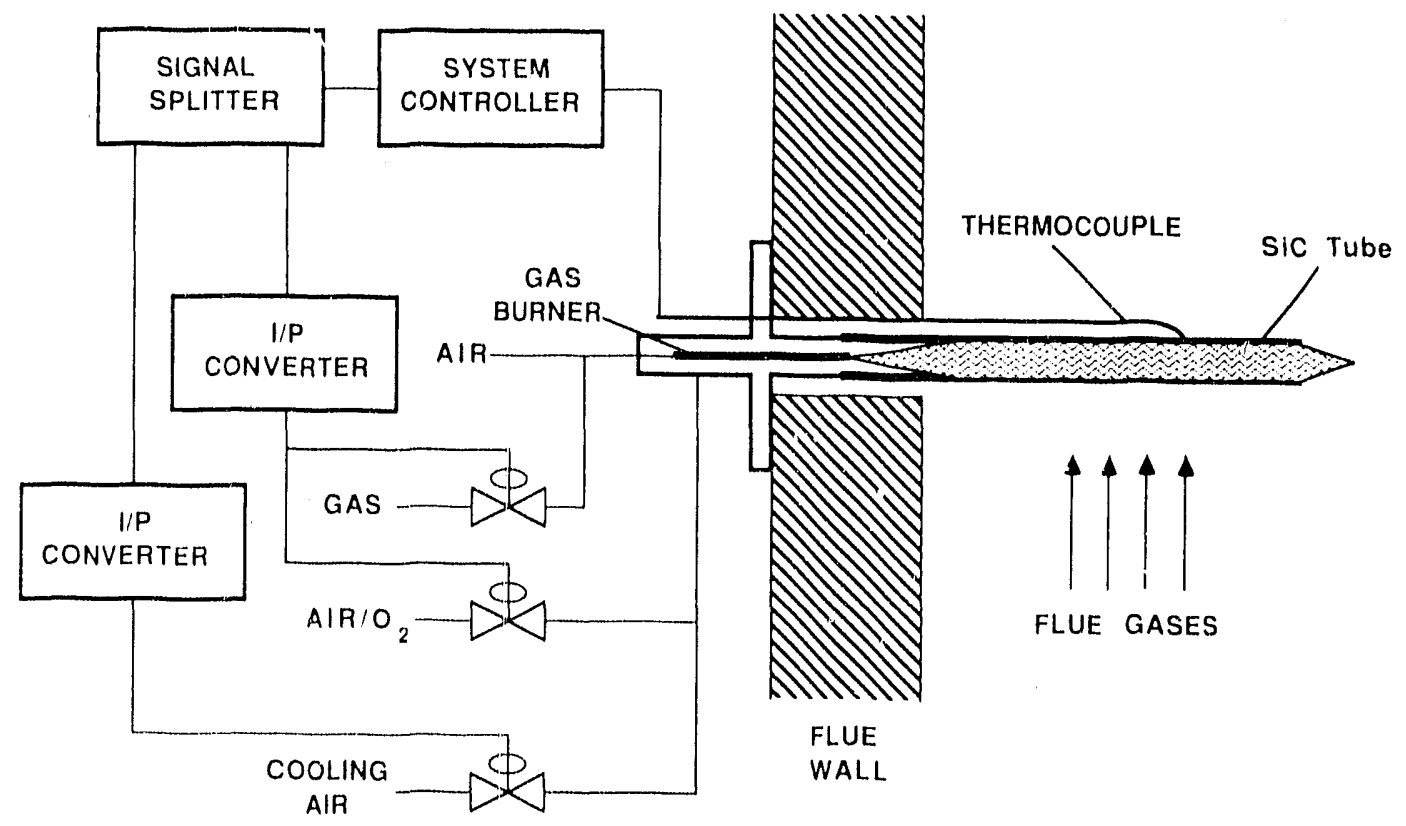

Fig. 1. Schematic of corrosion probe. 
flowing through the bore provides cooling. A double-spiral Sic electric heating element was initially tried as a heat source in the probe, but gas combustion in the bore was found to be superior in terms of maximum temperature and temperature uniformity. A micropronessor-bised instrument* accomplishes temperature control. This device measures the probe temperature by means of an attached thermocouple and computes an appropriate output signal to drive the proportional pneumatic air and fuel-gas flow contiol valves via the current-to-pressure (I/P) converters. The output from the process controller is a 4- to $20-\mathrm{mA}$ signal, with a value of $12 \mathrm{~mA}$ used as a control "null" point. A higher signal opens both the air and fuel-gas control valves, while a lower signal allows only cooling air to flow. Gas combustion in the probe is initiated by a high-voltage discharge in the end fixture at the inlet end of the SiC tube. A $3000-V$ dc power supply with suitable current-limiting resistors continuously generates the spark discharge. Figure 2 shows the prototype probe being test-fired in the laboratory.

A Hexoloy SA SiC ${ }^{\dagger}$ tube with nominal measurements of $25.4 \mathrm{~mm}$ OD $x$ $19.1 \mathrm{~mm}$ ID $\times 91 \mathrm{~cm}$ lang formed the specimen portion of the probe. This material was selected because it possesses many of the properties needed for heat-exchanger applications, e.g., high-temperature strength, oxidation resistance, thermal shock resistance, and avallability in the form of tubes. Most DOE-sponsored ceramic heat exchanger projects in recent years have selected a silicon carbide ceramic for the primary heat-transfer element. Two type-s thermocouples in oval, double-bore alumina insulators were attached to the outer surface of the SiC tube at locations measuring about $30 \mathrm{~cm}$ from each end. The insulators were secured to the tube at several locations with platinum wire covered with an alumina cement. One thermocouple connected to the temperature controller served as the control sensor, while the other was connected to a temperature recorder. The axial distance between the thermocouples was about $30 \mathrm{~cm}$.

\footnotetext{
*570 Series, Barber-Colman Company, Loves Park, 111.

†Carborundum Company, Niagara falls, N.Y.
} 


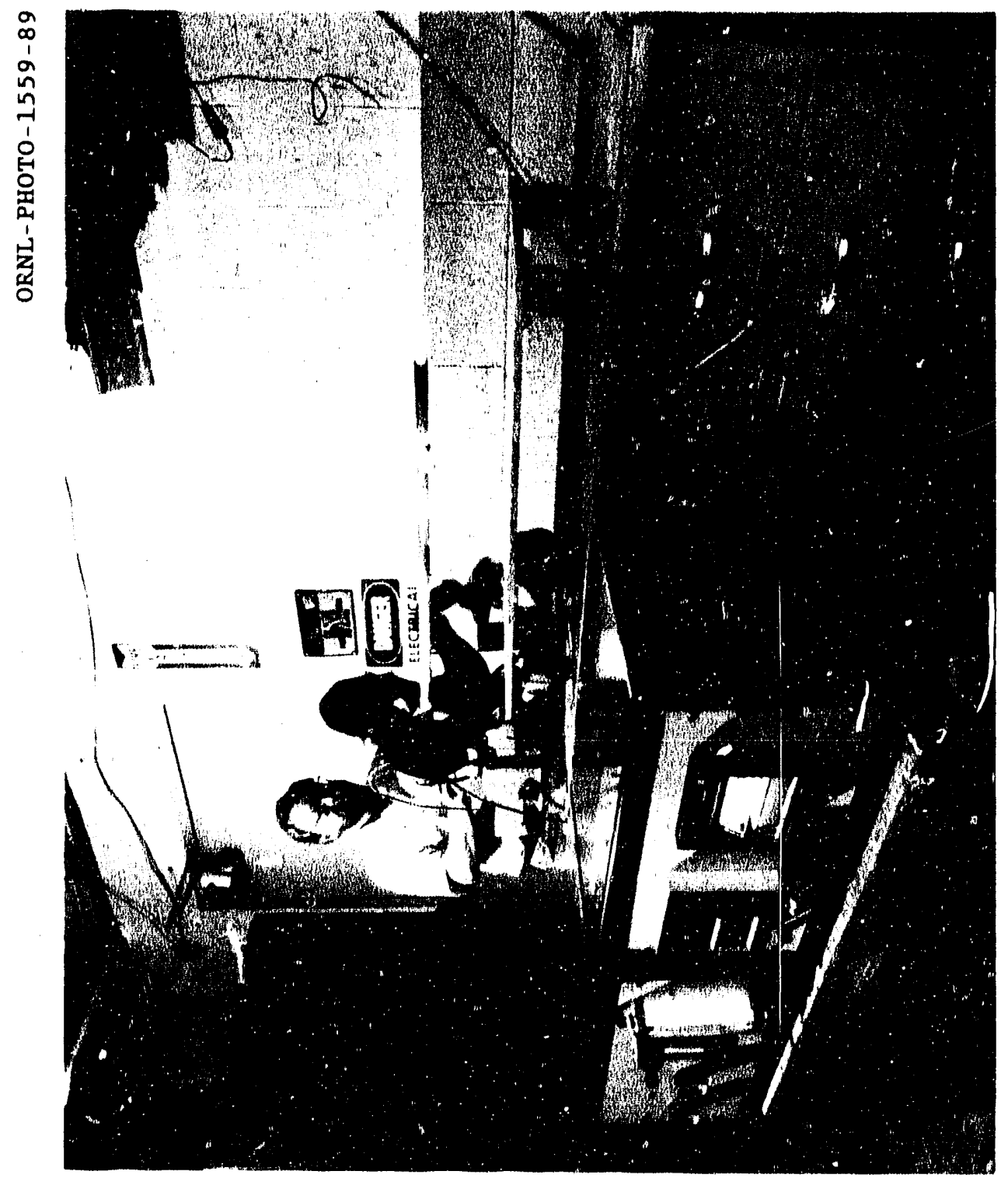

D 
The method of thermocouple attachment on the prototype probe was inadequate, and the use of only one test material (SiC) was undesirable. Both deficlencies were addressed in the advanced probe, shown schematically in Fig. 3. The SiC tube is retained both as a specimen and as a support for other ceramic specimens. The tubular ceramic specimens are attached to the SiC core tube by means of a cemint. Each specimen has a longitudinal slot to accommodate one or more thermocouples in double-bore insulators (Fig. 4). The slot width at the outer surface of the specimen is slightly less than the large diameter of the oval insulator; therefore, the insulator is captured in the slot and is secured further by an alumina cement. The alumina cement in the annulus between specimen and core tube contains 50 wt \& SiC powder. The SIC powder serves as an inert filler and decreases the amount of shrinkage during sintering of the cement. The powder may also increase the thermal conductivity of the cement, but this possibility was not determined by measurement.

ORNL-DWG-90-13908

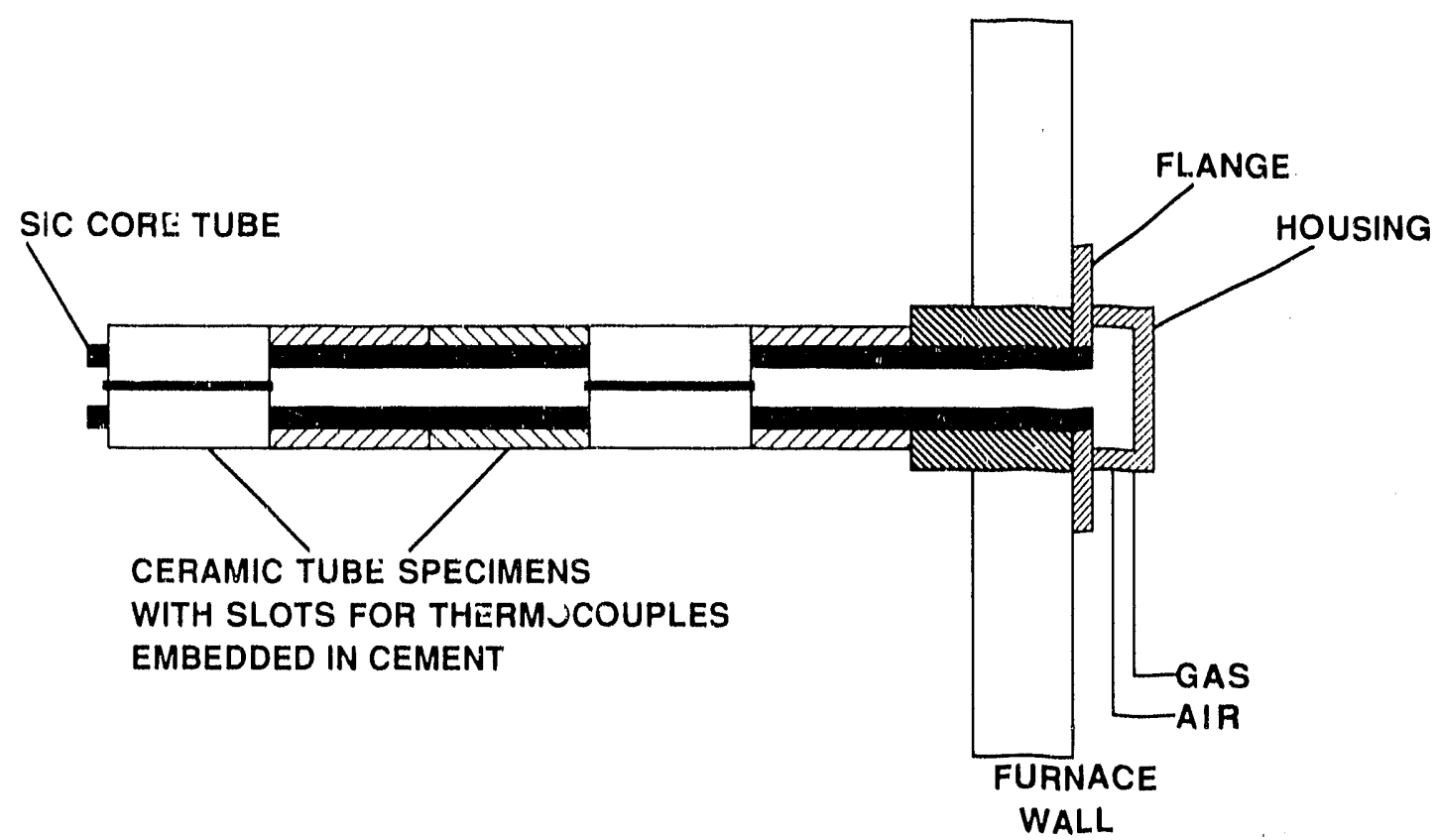

Fig. 3. Schematic of advanced corrosion probe with specimens of different materials. 
ORNL-DWG-90-13909

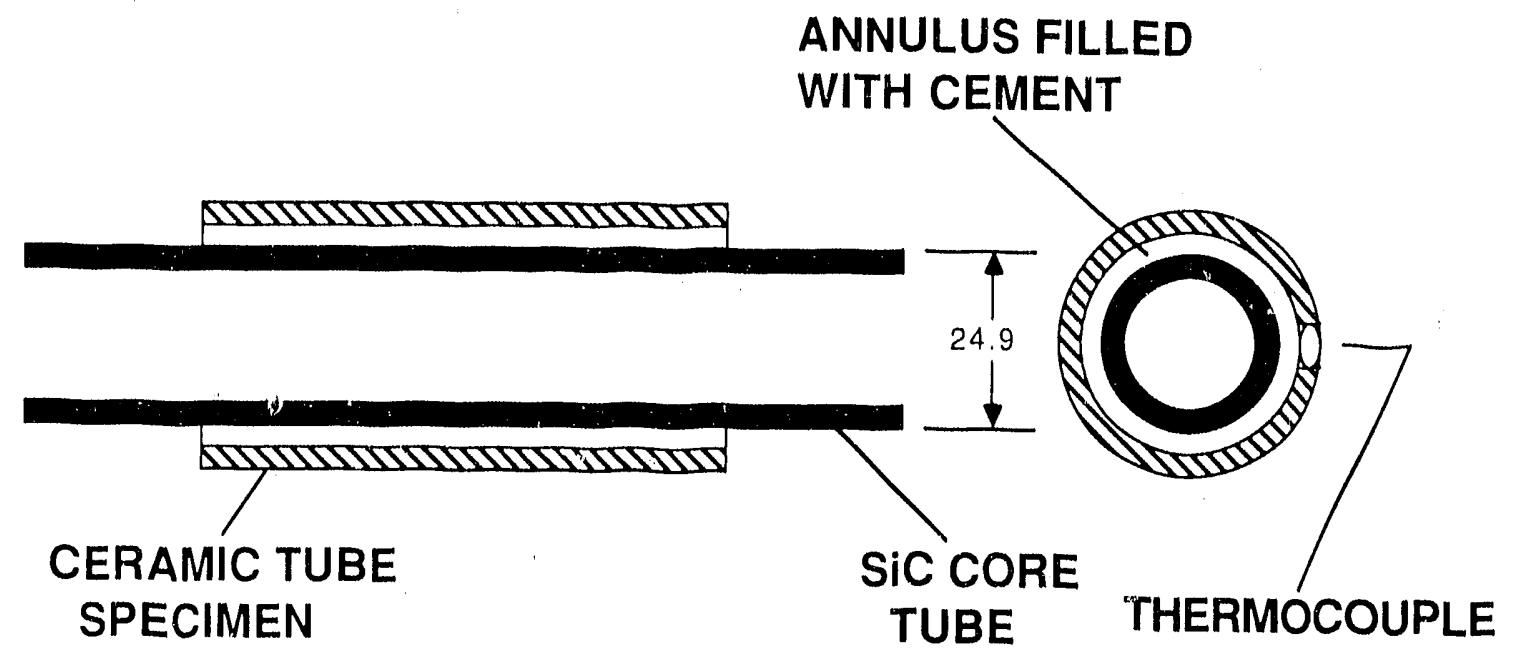

Fig, 4. Schematic of assembly of a specimen onto the SiC core tube.

Two alumina cements were investigated for this application. One cement, designated ACi010* for this study, contained approximately 928 $\mathrm{Al}_{2} \mathrm{O}_{3}$ and $78 \mathrm{SiO}_{2}$; the other, designated $\mathrm{KT} 95,{ }^{\dagger}$ contained approximately $848 \mathrm{Al}_{2} \mathrm{O}_{3}$ and $148 \mathrm{CaO}$. Slotted specimens of $\mathrm{Al}_{2} \mathrm{O}_{3}$ and mullite were attached to SiC core tubes with each cement alone and with each cement containing 25 and 50 wt $8 \mathrm{SiC}$ powder. The specimens were thermally cycled ten times between 20 and $1300^{\circ} \mathrm{C}$ at a heating rate of about $220^{\circ} \mathrm{C} / \mathrm{min}$. The $\mathrm{Al}_{2} \mathrm{O}_{3}$ specimen attached with KT95-50 wt \& $\mathrm{SiC}$ broke by axial cracking, and cracks were present in the KT95 coment in the other two specimens. No cracks or other evidence of degradation were evident in the specimens attached with $\mathrm{AC} 1010$ and AC1010-SiC powder mixtures; therefore, the AC1010-50 wt \& SiC mixture was selected for attaching specimens onto the SiC core tube of the advanced probe.

Several oxide ceramics were selected as specimens for the advanced probe: $\mathrm{Al}_{2} \mathrm{O}_{3}$, mullite $\left(3 \mathrm{Al}_{2} \mathrm{O}_{3} \cdot 2 \mathrm{SiO}_{2}\right), \mathrm{ZrO}_{2}$ stabilized with $\mathrm{Y}_{2} \mathrm{O}_{3}$ $\left[\mathrm{ZrO}_{2}\left(\mathrm{Y}_{2} \mathrm{O}_{3}\right)\right]$, and $\mathrm{SiC}$ whisker-toughened $\mathrm{Al}_{2} \mathrm{O}_{3}\left(\mathrm{Al}_{2} \mathrm{O}_{3}-\mathrm{SiCw}\right)$. Previous industrial-furnace exposure tests had showed that these four materials have

\footnotetext{
*Alfa Products, Morton Thiokol, Inc, Danvers, Mass.

Babcock \& Wilcox Company, Augusta, Ga.
} 
better resistance than silicon-based ceramics to combustion atmospheres containing alkali compounds. ${ }^{5,6}$ Their corrosion behavior, therefore, could be comparei to that of the SA SiC core tube, which, being exposed to the flue gases in several regions, formed a fifth specimen material. The oxides were in the form of tubes with inner diameters ranging from 26.6 to $30.9 \mathrm{~mm}$ as compared to the $24.9-\mathrm{mm}$ OD of the SiC core tube. Therefore, the annulus to be filled with cement varied from about 0.85 to $3 \mathrm{~mm}$ in thickness, depending on the specimen. Rubber 0-rings or strips of masking tape 3 to $4 \mathrm{~mm}$ wide ware used as temporary spacers to center, the specimens on the Sic tule while filling the annulus through the slots in the specimens. The cement, mixed with water to prepare a thick paste, hardened sufficiently in about $1 \mathrm{~h}$ to allow the spacers to be removed. After the four specimens and two thermocouples were cemented in place, the probe was heated to $1260^{\circ} \mathrm{C}$ and held for $2 \mathrm{~h}$ to sinter the cement. Figure 5 shows the advanced probe before testing in the CRNL steam plant furnace. A type-S thermocouple designated $T 1$ was located about $6 \mathrm{~mm}$ from the outer end of the zirconia specimen, and another thermocouple designated $T 2$ was located about $6 \mathrm{~mm}$ from the inner end of the mullite specimen, a separation distance of about $27 \mathrm{~mm}$. $T 1$ and $T 2$ also designate the temperatures indicated by these thermocouples.

As shown in Table 2, the outer diameters of the oxide specimens ranged from 30.6 to $35.6 \mathrm{~mm}$, and the lengths were 50.8 or $52.6 \mathrm{~mm}$. Table 2 also shows that the coefficients of thermal expansion (CTE) of the oxide ceramics range from $5.5 \times 10^{-6}$ to $10.5 \times 10^{-6} /{ }^{\circ} \mathrm{C}$. Because the CTE of SiC is about $5 \times 10^{-6} /{ }^{\circ} \mathrm{C}$, each of the specimens will expand more than $\mathrm{SiC}$. During heating of: the SiC tube by internal-gas combustion, the temperature of the specimens will lag behind that of the tube because heat must be transferred across the cement-filled annulus. The presence of SiC powder in the cement might enhance the thermal conductivity of the cement and minimize the temperature lag. However, the possibility exists that rapid heating and expansion of the $S i C$ tube by internal-gas combustion would stress the oxide specimens, especially mullite.

Preparation of the advanced probe required considerable effort and expense. The cost of components, materials, and labor for machining, assembly, and installation at the test site is estimated to be $\$ 25,000$. 


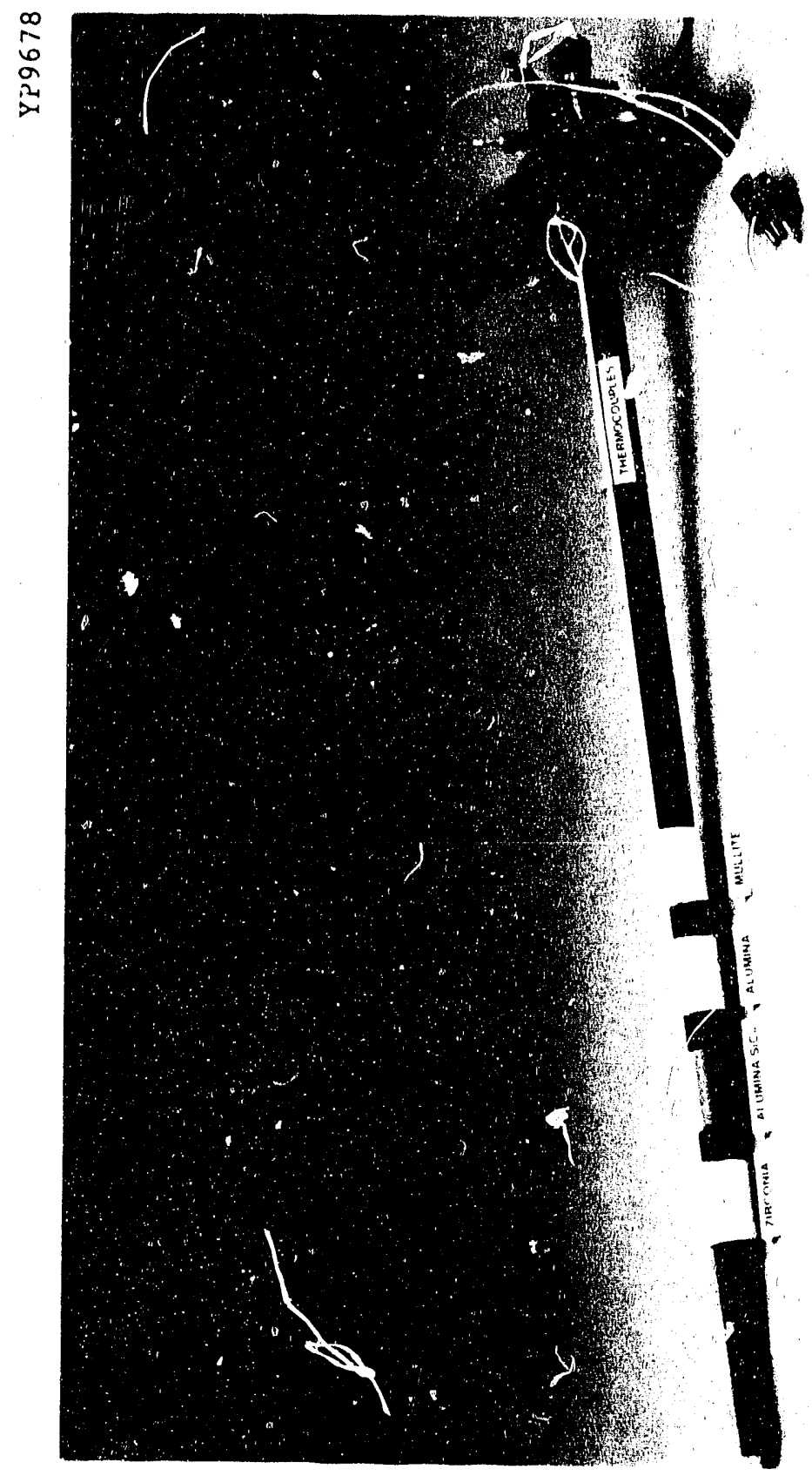

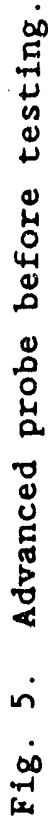


Table 2. Dimensions and CTEs of oxide specimens

\begin{tabular}{|c|c|c|c|c|}
\hline Material & $\begin{array}{c}\text { Outer } \\
\text { diameter } \\
(\mathrm{mm})\end{array}$ & $\begin{array}{c}\text { Inner } \\
\text { diameter } \\
(\mathrm{mm})\end{array}$ & $\begin{array}{l}\text { Length } \\
(\mathrm{mm})\end{array}$ & $\begin{array}{c}\mathrm{CTE}^{a} \\
(\mathrm{in} \cdot / \mathrm{in} \cdot \bullet \mathrm{C})\end{array}$ \\
\hline $\mathrm{Al}_{2} \mathrm{O}_{3}$ & 34.3 & 28.3 & 50.8 & $8.5 \mathrm{E}-06$ \\
\hline Mullite & 32.7 & 27.6 & 50.8 & $5.5 E-06$ \\
\hline $\mathrm{ZrO}_{2}\left(\mathrm{Y}_{2} \mathrm{O}_{3}\right)$ & 35.6 & 30.9 & 52.6 & $10.5 E-06$ \\
\hline $\mathrm{Al}_{2} \mathrm{O}_{3}-\mathrm{SiCw}$ & 30.6 & 26.6 & 50.8 & $7.5 \mathrm{E}-06$ \\
\hline
\end{tabular}

PROBE TESTING

A heating test of the prototype probe was conducted in the laboratory using propane and oxygen. Propane was used because natural gas was not available for the probe at the ORNL steam plant, where the probe was to be tested later; presumably, natural gas could be used as well as propane. Attempts to obtain a stable flame in the bore with propane-air mixtures were mostly unsuccessful because the flame would be quenched or transported to the rit end of the $\mathrm{SiC}$ tube by the combustion air. However, ignition was easily achieved near the inlet end of the SiC tube with a propaneoxygen mixture. A probe temperature of about $1000^{\circ} \mathrm{C}$ was obtained in the laboratory (Fig. 2) with average flow rates of about 27 and $135 \mathrm{~L} / \mathrm{min}(1.2$ and $6.8 \mathrm{~mol} / \mathrm{min}$ ) of propane and oxygen, respectively. Some air wass also drawn into the mixture by the gas supply tube. The prototype probe was then installed in a boiler firebox at the ORNL steam plant, which burned coal during an exposure period of about 6 weeks. This test aimed to determine the capability of the system to control temperature while the probe was exposed to flue gases ranging in temperature from approximately 950 to $1200^{\circ} \mathrm{C}$. Without auxiliary heating or cooling, the probe rapidly reached temperature equilibrium with the flue-gas temperature of $1200^{\circ} \mathrm{C}$. Then, cooling air was forced through the nrobe to control the temperature at a value below the flue-gas temperature. With an air-flow rate of about $163 \mathrm{~L} / \mathrm{min}(5.8 \mathrm{cfm})$, the minimum temperatures were about 1100 and $1200^{\circ} \mathrm{C}$ for the inlet end and outlet end ( $30 \mathrm{~cm}$ apart) thermocouples, respectively, 
indicating that temperature equilibrium was attained between the probe and the cooling air during passage through the bore. Subsequeit calculations suggested that the cooling air would attain the temperature of the probe at about the midpoint for an air-flow rate of $-283 \mathrm{~L} / \mathrm{min}$ ani that the location of temperature equilibrium moved closer to the inlet end for lower flow rates.

Unfortunately, the safety approvals required for burning gas in the bore of the probe could not be compluted until the probe had been in the furnace for about 5 reeks. By that time both thermocouples had failed, and the furrace had been temporarily shut down. Before withdrawing the probe, however, the gas-ignition system was tested and found to be operating satisfactorily. The probe, when removed, was covered with thick deposits of ash and slag from the coal combustion environment (Fig. 6). The cement used to attach the thermocouples had spalled, and the thermocouple wires had reacted with the deposits. The method of thermocouple attachment obviously had to be improved for successful use of the probe. The Sic tube wall also exhibited a surface recession of 0.3 to $0.4 \mathrm{~mm}$ in the hottest part (midpoint to outer end) on the upstream side, indicating the corrosive nature of the environment.

When the advanced probe was installed, the furnace was initially heated with natural gas so that testing could be conducted in the absence of fouling deposits; however, the maximum temperature attainable at the probe location was only about $400^{\circ} \mathrm{C}$. After performing some tests at that temperature, the furnace was heated to about $1200^{\circ} \mathrm{C}$ with coal for further testing. After only $24 \mathrm{~h}$ the probe had accumulated ash and slag deposits similar to those shown in Fig. 6.

In an actual application the instrumentation would be required to maintain the probe at a constant temperature as the furnace temperature changed. Control would be accomplished by cooling or heating as required. An objective of the tests was to determine the range of temperature control with the available cooling and heating capacities. Figure 7 shows the results of a cooling test at a nominal furnace temperature of $400^{\circ} \mathrm{C}$. The initial temperature $T 2$ was about $30^{\circ} \mathrm{C}$ lower than $T 1$ because thermocouple $T 1$ was located deeper into the furnace. (T'1 was about $6 \mathrm{~mm}$ from the outer end of the zirconia specimen, and $T 2$ was about $6 \mathrm{~mm}$ from the inner end of the 


$$
1
$$


ORNL-DWG - $90-13910$

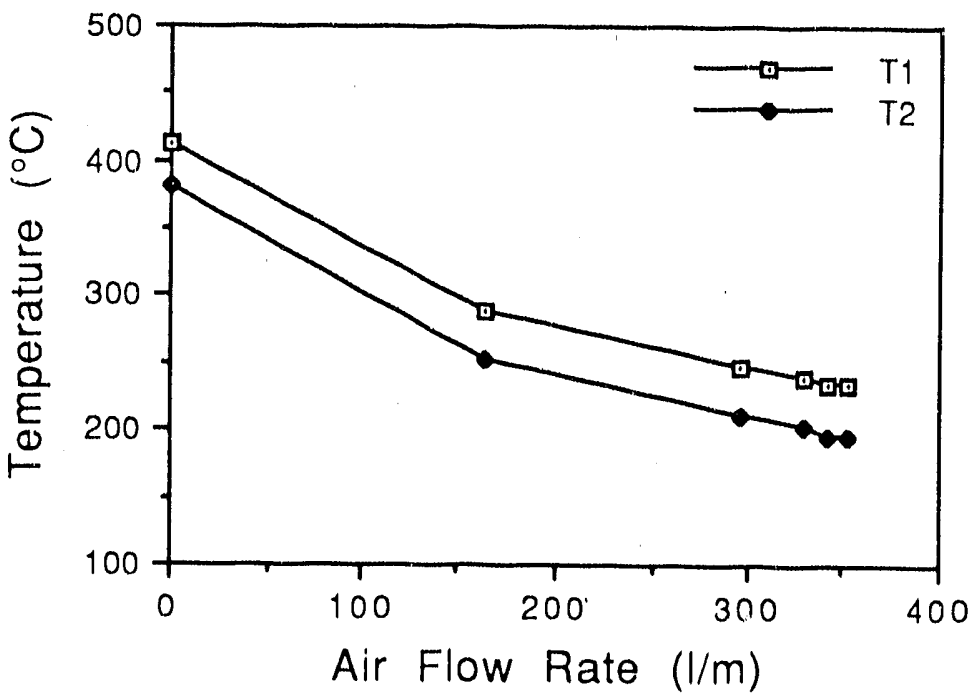

Fig. 7. Results of a cooling test at a nominal furnace temperature of $400^{\circ} \mathrm{C}$.

mullite specimen.) The probe temperature decreased about $200^{\circ} \mathrm{C}$ as the flow rate of air increased to about $350 \mathrm{~L} / \mathrm{mir}$. The final $\mathrm{T} 2$ was about $40^{\circ} \mathrm{C}$ lower than $T 1$; therefore, cooling increased the axial-temperature difference between the specimens represented by $T 1$ and $T 2$.

The opposite effect occurred in $T 1$ and $T 2$ during a heating test (Fig, 8). As the set-point (SP) temperature advanced, the control system initially applied cooling air, then it proceeded into the heating mode. Within a few minutes the cooling air-flow rate decreased to zero, and gas combustion occurred. During the next few minutes, temperature $T 2$ exceeded $T 1$. When $T 1$ reached the set point, $T 2$ was about $30^{\circ} \mathrm{C}$ higher. As in the case of the cooling test, $T 2$ was affected more than $T 1$, and, again, an axial-temperature gradient was imposed on the specimens. The reason for this behavior, of course, is that the temperature of either cooling air or gas-combustion products increases as the gases proceed through the bore. When the air or combustion products reach $T 1$, their temperature has changed from the value at $T 2$ because of a tendency towards thermal equilibration with the probe.

Heat-exchanger tubes being used to preheat air typically operate at a temperature about $200^{\circ} \mathrm{C}$ below the flue-gas temperature. Therefore, the 
ORNL-DWG - $90-13911$

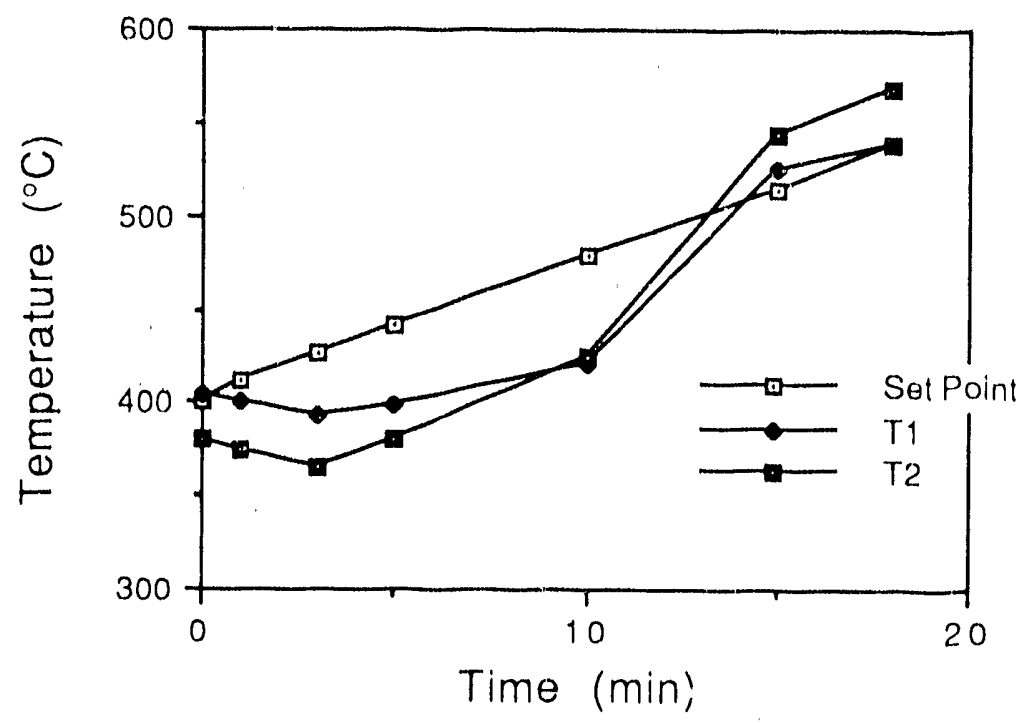

Fig. 8. Results of a heating test at a nominal furnace temperatuxe of $400^{\circ} \mathrm{C}$.

corrosion probe would often be required to simulate heat-exchanger tube exposure, that is, operate in the cooling mode. Unfortunately, at a nominal furnace temperature of 1000 to $11.00^{\circ} \mathrm{C}$ the effects of cooling and heating on axial-temperature gradients were even greater than at $400^{\circ} \mathrm{C}$. Figure 9 shows that increasing cooling increased the axial-temperatuve gradient between $T 1$ and $T 2$. (The upturn in temperature at the highest flow rates was caused by a fluctuation in furnace temperature.) These results show that operating the probe in the cooling mode imposes a substantial axial-temperature gradient on the specimens and that the greater the amount of cooling, the larger the gradient. On the other hand, when the probe was operated in the heating mode to raise the temperature above the flue-gas temperature, the heating capacity was very limit d (Fig. 10). At a nominal furnace temperature of $1100^{\circ} \mathrm{C}$, heating affected $T 2$ more than $T 1$ as was the case at a furnace temperature of $400^{\circ} \mathrm{C}, T 1$ increased only $50^{\circ} \mathrm{C}$ and never reached the set point during the heating test, while $T 2$ gradually increased to the set point. This small heating effect consumed oxygen at a rate of $\approx 2 \mathrm{~mol} / \mathrm{min}$, a rate that would consune a standard size cylinder of oxygen containing $\approx 5000 \mathrm{~L}$ (at STP) in $\approx 2 \mathrm{~h}$. During this test the gas mixture was substoichiometric with respect to oxygen: if more oxygen had been used, the 


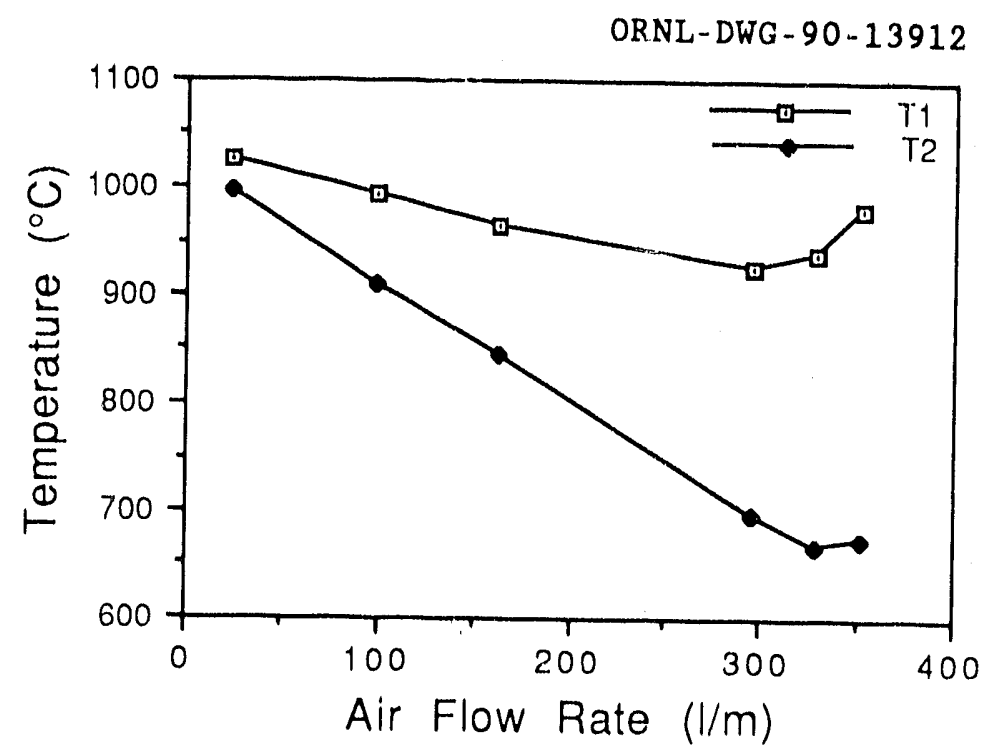

Fig. 9. Results of a cooling test at a nominal furnace temperature of $1000^{\circ} \mathrm{C}$.

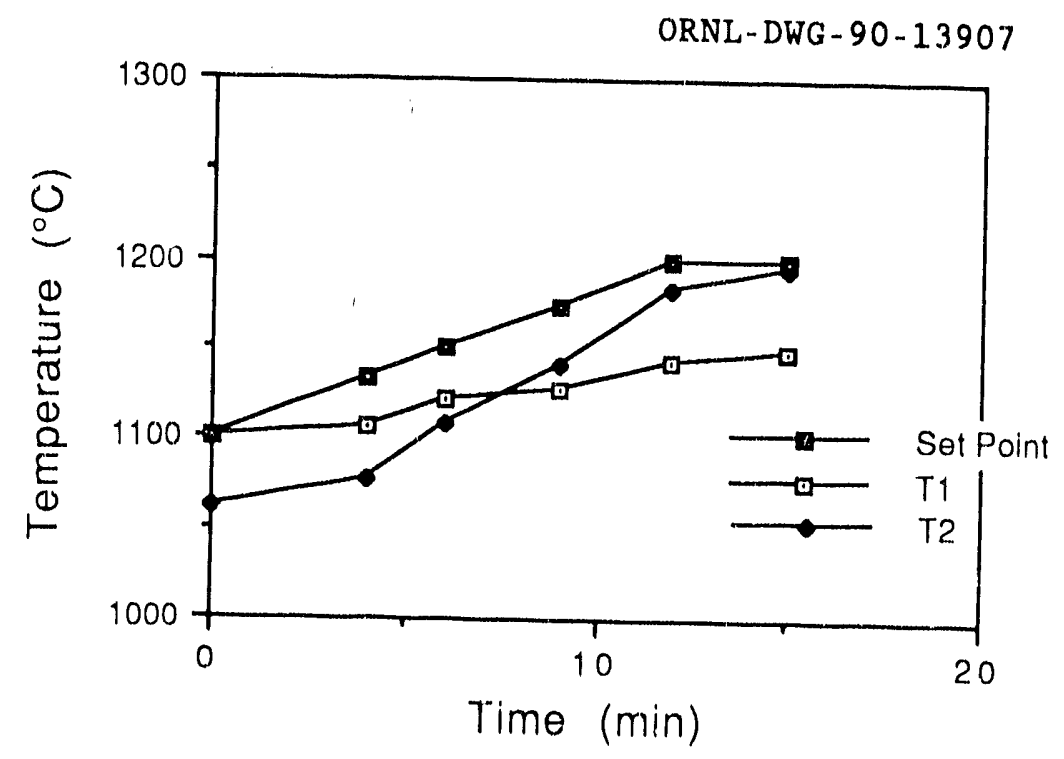

Fig. 10. Results of a heating test at a nominal furnace temperature of $1100^{\circ} \mathrm{C}$. 
heating effect would have been larger, but the oxygen consumption rate would have been even higher. Therefore the cost of heating a probe by internal-gis combustion is likely to be prohibitively expensive.

The results of testing the probe in an industrial-type furnace can only be interpreted as unsatisfactory for the intended purpose (Figs, 7-10). The limited heat Ing capacity by internal-gas combustion required an extremely large amount of oxygen. Alternatively, internal air cooling caused a substantial axial-temperature gradient. The latter effect was anticipated qualitatively, but not to the extent actually experienced. A furnace with fluctuating temperatures would require varying amounts of cooling air, which would cause the temperature of the specimens to vary accordingly. The tests showed that neither the heating nor the cooling capacity could significantly affect $T 1$, the thermocouple farthest from the inlet end. When the costs of the temperature-control equipment, construction of the probe, and monitoring the probe during an exposure are balanced against the data obtained from a probe with such poor temperature control, we must conclude that a fully controlled probe is not cost-effective.

The temperatures $T 1$ and $T 2$ would be approximately the same at very low and very high flow rates of cooling air. At very low flow rates, $T 1 \approx T 2 \approx T_{G}$, where $T_{G}$ is the flue-gas temperature. This is a case of essentially no control. At very high flow rates $T 2=T 1 * T_{G}$, a case where both temperatures are forced very low simply to make them approximately the same. The latter case may not be useful for corrosion testing because the resulting low temperatures are not representative of heat exchangers. The position of specimens along the length of the probe affects their temperature, and their spacing affects the axial-temperature gradient. We have determined by testing that these problems are too complex to be resolved in the relatively simple flue-gas corrosion probe.

\section{ALI'ERNATE APPROACHES}

If the corrosion probe is not cost-effective, how should hightemperature corrosion data be obtained? The noncontrolled method mentioned early in this report, i.e., installation of a large number of specimens of 
different materials in several industrial furnaces, should be used to separate the obviously better materials from the group. The better candidates shruld be further evaluated in terms of factors slich as ease of fabrication, strength, thermal shock resistance, and cost to select only a few viable candidates for heat-exchanger materials. Then, tubular probes, each consisting of a single matertal like the previously discussed prototype probe, would be prepared. Using one material per probe would eliminate the cost of machin!ng and attaching slotted specimens, as was done for the advanced probe; however, a method of thermocouple attachment would still have to be devised. Several such probes, equipped with thermocouples and provided with controlled internal cooling (no internal heating), would be installed in an industrial furnace. Cooling the tubular probes would cause axial-temperature gradients, thereby simulating the condition in heatexchanger tubes. Following an exposure, the extent of corrosion of the probes would be determined. One disadvantage of this approach is that separate temperature-control systems would be required for each material, because a probe would consist of only one material; the previously discussed advanced probe consisted of several materials. Thus, the cost of obtaining detailed corrosion data by this conservative approach would be substantia1.

An alternate, less conservative approach would utilize the corrosion results of numerous specimens in several different furnaces to identify a few viable candidates, as before. Final selection would omit the use of probes described above and rely on physical and mechanical properties and cost and avaliability (the method used in previous DOE-sponsored heatexchanger projects). Surveillance specimens of the same material as the heat-exchanger tubes could be installed in the heat exchanger for periodic retrieval and examination, or actual tubes could be periodically removed for examination. In this manner, the progress of corrosion under actual heat-exchanger conditions could be assessed. This approach carries more risk because of less extensive testing but would be less expensive. 
CONCLUSIONS

The work that has been performed supports the following conclusions.

1. Either Internal heating or cooling fimposes an axtal-temperature gradient on the probe and on any set: of specimens arranged along the axis of the probe. This precludes using a probe with multiple spectimens unless different temperatures are destred; however, achieving the desired tempera. ture in a particular specimen would probably not be predictable without some experience with this type of probe.

2. Internal heating by gas combustion requires oxygen for rellable ignition and a stable flame, but the cost of oxygen for extended heating would be prohibitive.

3. Internal heating by gas combustion was minimal and could not significantly affect the heat balance with the furnace; therefore, this type of auxiliary heating should not be used.

4. Alternate approaches to the corrosion probe include (a) exposure tests of numerous materials without temperature control to identify the better materials within e group; (b) further investigation of corrosion of a selected, limited numbe: of materials in controlled cooling probes that simulate temperature gradients in heat-exchanger tubes; and (c) surveillance specimens installed in an actual heat exchanger to montor corrosion during use. Options (a) and (b) would involve the highest cost and the lowest risk, while (a) and (c) would involve the lowest cost and higher risk.

\section{ACKNOWLEDGMENTS}

The authors acknowledge the assistance of others in the performance of this work, especlally K. S, Weaver and N. D. McCollough, Sr., who assembled the instrumentation and probe end fixture and Installed the probe in the boller firebox at the steall plant. We also thank personnel of the Plant \& Equipment Division for allowing the probe to be tested in the boiler firebox. In particular, we wish to thank J. L. Baxter for operating the boller on gas or coal especially for our test. His cooperation in all 
phases of tosting was greatly appreclated. Finally, wo appreciate D. L. Balltrip for preparing the final manuscript.

\section{REFERENCES}

1. A, J. Hayes, W. W. Llang, S, L. Richlen, and E, S, Tabb, ads., Industrlal Heat Exchangers, proceedings of a conference sponsored by The American Society for Metals, Gas Research Institute, and U.S. Department of Energy held at Pittsburgh, Pa, November 6-8, 1985, The American Society for Metals, Metals Park, Oh1o, 1985.

2. J, B. Patton, "Ceramics and High-Temperature Wastentleat Recovery," pp. 15-20 in Ceramics in Heat Exchangers, Advances in Ceramics, Vo1. 14, eds. B, D. Foster and J, B, Patton, The American Ceramic Society, Columbus, Ohio, 1985.

3. A. D. Russe11, C. E. Smeltzer, and M. E. Ward, Waste Heat. Recuperation for Aluminum Furnaces, GRI-81/0160, Gas Research Institute, Chicago, Apri1 1983.

4. J, I. Federer and T. N. Tlegs, "Analysis of Candidate silicon Carbide Recuperator Materials Exposed to Industrial. Furnace Environments," pp. 315-34 in Ceramlcs in Heat Exchangers, Advances in Cexamics, Vo1. 14, eds. B. D. Foster and J. B. Patton, The American Ceramio Society, Columbus, ohio, 1985 .

5. J. I. Federer and P. J. Jones, Oxidation/Corrosion of Metallic and Ceramic Materlals in an Aluminum Remelt Furnace, ORNL/TM-9741, Martin Marietta Energy Systems, Inc., Oak Ridge Nat1, Lab, December 1985.

6. J, I. Federer, "High-Temperature Corrosion of Heat Exchanger Matertals," In proceedings of The International Symposium on Corrosion and Corrosive Degradation of Ceramics, the Ftrst International Ceranic Science \& Technology Congress, Anahein, Calif, October 31-November 3, 1989, to be published.

7. W. J. Marner and S. P. Henslee, "A Survey of Gas-Side Fouling Measuring Devices," pp. 209-26 in Industrial Heat Exchangers, eds. A. J. Hayes, W. W. Llang, S. L. Rlchlen, and E. S. Labb, proceedings of a conference sponsored by the American Soclety for Metals, Gas Research Institute, and U.S. Department of Energy held at Pittsburgh, Pa., 
November 6-8, 1985, The American Soclety for Metals, Metals Park, Orto, 1985.

8. W. J, Marner and K. S. MacDavid, Development of a Gas-Side Fouling Measuring Device, DOE/ID/12138-7(DE87014462), U,S. DOE, Office of Industrial Programs, May 1987.

9. J, A. McEvers and J. I. Federer, "Design of a Controlled Temperature Flue Gas Corrosion Probe," pp. 423-28 in ASME Proceedings of the 1988 National Heat Transfer Conference, Houstion, Tex., July 24-27, 1988, ed. H, R. Jacobs, IITD-96, Vo1, 1, The American Society of Mechanica1 Engineers, New York, 1988.

10. J. A. McEvers, Design of a Controlled Temperature Flue Gas Corrosion Probe, Master's thesis, The University of Tennessee, Knoxville, T'enn., August 1988. 


\section{APPENDIX}

J. A, McEvers and J, I, Federer, "Design of a Controlled Temperature Flue Gas Corrosion Probe," pp. 423-28 in ASME Proceedings of the 1988 National Heat Transfer Conference, Houston, Tex., July 24-27, 1988, ed. H. R. Jacobs, HTD-96, Vo1. 1, The American Society of Mechanical Engineers, New York, 1988. 


\title{
APPENDIX
}

\section{DESIGN OF A CONTROLLED TEMPERATURE FLUE GAS CORROSION PROBE*}

\author{
J. A. McEvers and J. I. Federer \\ Oak Ridqe National Laooratory \\ Oak Ridge. Tennessee
}

\section{ABSTRACT}

The need to decermine suitable materials for use in industrial waste heat recovery systems requires assessuent of materials degradation in various flue gas environments. Such an assesswent generally involves exposing candidate caterials to the environments. then analyzing the effects of the exposure conditions. Degradition of macerials is related co flue gas chemiral composition. cemperature, and thermal. cycling behavins. Temperature variations, especially atycical thermal cycling coxplicate the task of characterizing such phenomena as corrosion races and corrosion mechanisms. A relacively constant cemperature would allow a more accurace determination of the effects of flue bas chemical composition and cemperature. In response to this need. a Elue gas corrosion probe has been jesigned for exposice cests of materials. The probe allows materiais to be rested at nominally constant temperatures within a wide span of either corstane or changing flue gas temperatures. This paper describes the design and fabrication of the corrosion probe system.

\section{:ITRODUCTION}

Exposure cests in industrial furnaces have been used in recent years to compare the high-cemperature corrosion of various candidate materials for heat exchangers. Specimens have been placed in the flues of aluninui remelt furnaces (Russeli et al., 1983. Federer et al., 1985, and Federel and Jones, 1985). steel soaking pits and steel reheat furnaces (Federer et al.. 1985), and a glass furnace (Weber and Tennery, 1979). In most cases specimens were exposed to ambient furnace conditions far a time period determined by the furnace production schedule. Specimens were installed during a furnace shutdown. and were removed during a subsequent shutdown. During the exposure period cemperatures sometimes could be

*Research sponsored by the Waste Energy Recovery Progran, Office of industrial Prograns. U.S. Department of Energy, under Contract No. DE-ACO5-840R21400 with Martin Mariecta Enezey systems, Inc. monitored and a temperature-time history determined. but specimen cemperature could not be controlled. Exposure conditions--maximum and minimum remperatures heating and cooling rates, temperature-time history, and composition of combustion products--were all dependent on production requirements. The disadvantages of this type of materials exposure test are as follows:

- Specimen temperature is not controlled, and sometimes is not weasured accurately.

- Flue gas cemperature cycles frequently in some furnaces, and therefore specimen temperacure also cycles.

- Corrosion data are based on a complicated temperature-time history.

- Corrosion data for a specific temperacure are not determined.

- The effect of temperature on corrosion rate is not determined.

- Extrapolation of corrosion data to other furnaces with different temperature-time histories is difficult.

- Stresses induced by thermal cycling cause additional degradation.

Exposire of materials to ambient conditions within a particular furnace might provide useful information for an intended application, especially if the furnace operated normally. Alternatively, the results wight serve only as a guide to materials behavior because of atyplcal temperature-time history. In tha case, the results would represent conditions unmatched in ocher furnaces of the sane cype, and would not be applicable under a different set of conditions. Furthermore, data interpretation is difficult if temperatures vary over a wide range due to inabllity to correlate corrosion rates with specific temperatures. As a resulc, either additlonal exposure tests would be required or results would have to be estimated. Estlmation of corcosion results is unwise if unanticipated fallure of a heat exchanger would result in production losses. A possible solution to this problea is instrumented, temperature-controlled corrosion probes. Ideally, several such probes would be operated at different temperatures of interest in a typical c smbustion environment. Preselected constant 
temperatures or temperature-time histories would be maintained by heating or cooling ws required. In this manner results would be obtained for test conditions representing a particular heat exchanger or for more generic conditions. The main feacures of a controlled. temperature corrosion probe are as follows:

- Thermocouples for monitoring temperatures

Internal heating to increase temperature

Internal cooling to decrease cemperature

Automatic temperature control

Continuous recording of temperature

Advantages and disadvantages of the two types of

exposure tests are presented in Table 1 . A

disadvantage of the corrosion probe is that relatively

few specimens can be tested in the current design,

which increases the cost per specimen per test. The

conventional exposure test, therefore, could be used to screen a large number of materials, and the corrosion probe could be used to obtain pertinent data for the better materials. Of course, companion specimens having r. temperature control could be installed along with the probe(s). Corrosion data representative of the temperature fluctuations of the furnace woulc be obtained with these specimens. Such data might be useful for a heat exchanger or that particular furnace. The probe data, on the other hand, could be applied to heat exchangers on other furnaces having different temperature-time hiscories.

Tule objective of this work was to develop a conceptual design for an instrumented, temperacure. controlled corrosion probe suitable for testing candidate heat exchanger materials (both metalic and ceramic) in high-temperature combustion environments. The conceptual design involves size, assembly features. heating and cooling methods, and temperature control instrumentation. The probe has a tubular configuration with temperature control provided by a regulated internal heater and by the flow of cooling air through the bore. The cooling method is similar to that empluyed in wetallic corrosion and fouling probes (Hoffman et al., 1987, Marner and Henslee, 1985, and Marner and MacDavid, 1987), which were designed to

Table 1. Comparison of corrosion test methods

\begin{tabular}{|c|c|c|}
\hline Comparison criteria & $\begin{array}{l}\text { Conventional } \\
\text { exposure test }\end{array}$ & $\begin{array}{l}\text { Controlled- } \\
\text { temparature } \\
\text { coriosion } \\
\text { piobe }\end{array}$ \\
\hline $\begin{array}{l}\text { Number of m.terials } \\
\text { per test }\end{array}$ & Many & Few \\
\hline Expense per specimen & Low & Moderate \\
\hline Temperature known & Yes & Yes \\
\hline Temperature controlled & No & Yes \\
\hline Temperature-time history & Complicated & Simple \\
\hline $\begin{array}{l}\text { Corrosion rate at } \\
\text { temperature of interest }\end{array}$ & No & Yes \\
\hline $\begin{array}{l}\text { Effect of temperature } \\
\text { on corrosion rate }\end{array}$ & No & Yes \\
\hline Extrapolatable data & No & Yes \\
\hline $\begin{array}{l}\text { Furnace shutdown required } \\
\text { for installation or } \\
\text { removal }\end{array}$ & Yes & No \\
\hline
\end{tabular}

operate at temperatures considerably less than flue gas temperatures by regulating the flow of air through a tubular configuration in contact with the flue gases. None of these probes contained a heat source for increasing the operating temperature.

A computer model was used to evaiuate the characteristics of the corrosion probe discussed here. The effects of size, spacings, cooling air flow rate, heater capacity, and flue gas temperature and flow rate were eviluated to determine the possible range of temperature conirol. The model permitted a theoretical determination of he effect of exposure conditions on probe performance before actual fabrication of the probe.

\section{DESIGN BASIS}

Although the probe is intended for use in various furnaces in which the flow rate and temperature of flue gases are different, the heater and air flow were sized for a typical industrial aluminum remelt furnace. The reference furnace burns natural gas with 108 more air than the stolchlometric amount required for combustion. At the highest firing rate (Table 2), the vurners produce $4.7 \mathrm{MW}(16 \mathrm{E}+06 \mathrm{Btu} / \mathrm{h})$ of heat and flue gas temperatures of about $1300^{\circ} \mathrm{C}\left(2400^{\circ} \mathrm{F}\right)$. At the lowest firing rate the quantities are $0.9 \mathrm{MW}(3 \mathrm{E}+06 \mathrm{Bcu} / \mathrm{h})$ and about $750^{\circ} \mathrm{C}\left(1400^{\circ} \mathrm{F}\right)$. The flue gases mostly consist of $\mathrm{N}_{2}, \mathrm{CO}_{2}, \mathrm{H}_{2} \mathrm{O}$, and $\mathrm{O}_{2}$ as shown in Table 2 . Figure 1 illustrates a possible flue gas temperature variation in an industrial furnace. The temperature increases rapidly from 750 to $1300^{\circ} \mathrm{C}$, holds for about $2 \mathrm{~h}$, then decreases to $750^{\circ} \mathrm{C}$. After $1 \mathrm{~h}$ at $750^{\circ} \mathrm{C}$, the cyc.e is repeated. The purpose of the probe control

Table 2. Reference furnace combustion conditions

\begin{tabular}{lcc}
\hline Combustion products & High fire & Low fire \\
\hline $\begin{array}{l}\text { Heat content } \\
\text { MW }\end{array}$ & 4.7 & 0.9 \\
Bi.u/h & 16 Et06 & 3 E+06 \\
Temperature & & \\
C & 1300 & 750 \\
F & 2400 & 1400 \\
Mass flow rate & & \\
kg/s & 1.69 & 0.29 \\
Ib/h & 13.385 & 2295 \\
\hline
\end{tabular}

$a_{-74} \mathrm{~N}_{2}, 138 \mathrm{CO}_{2}, 118 \mathrm{H}_{2} \mathrm{O}, 28 \mathrm{O}_{2}$.

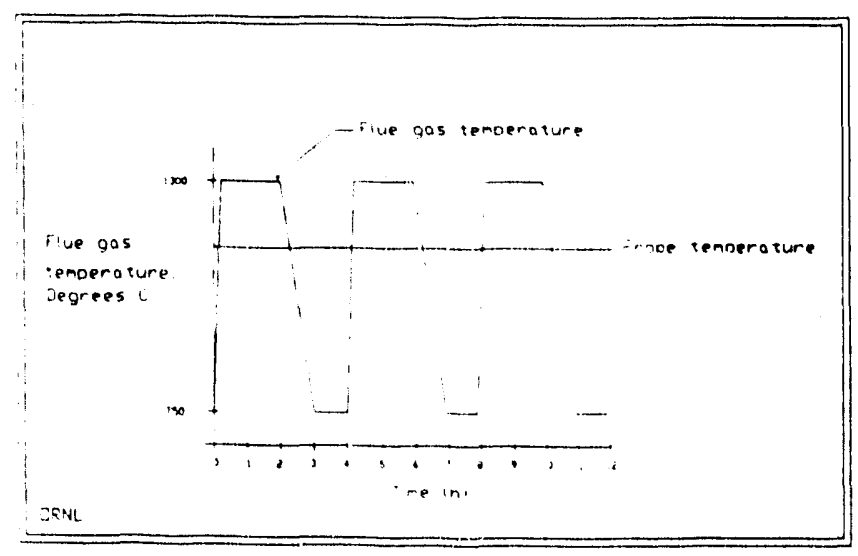

Figure 1. Example of flue gas vs. corrosion probe temperature. 
system is to maintain the probe at a constant temperature during the thermal cycles. Calculations werm conducted to determine the amount of internal heating and cooling required to maintain the temperature by adding heat when the flue gas temperature is below the probe setpoint and by cooling when the flue gas temperature is t.00 high.

\section{CHARACTERISTICS OF A CORROSION PROBE}

The corrosion probe was designed to provide features that are not available in conventional exposure tests:

- Install in and remove from an industrial furnace flue without affecting furnace operation.

- Automatically maintain the desirad temperature within a range of flue gas temperatures and flow rates.

- Provide a continuous, permanent temperature-time history.

The conceptual design is a tubular configuration

(Fig. 2) :omposed of the specimen (test section) and other commercially available components. The probe projects a predetermined distance through a port in the flue wall, and is immersed in flue gases in a crossflow mode. The test section in the reference design is $-2.5 \mathrm{~cm}$ OD $\times 1.9 \mathrm{~cm}$ ID $\times 38 \mathrm{~cm}$ long. These dimensions $11 m i t$ the size and capacity of the internal heater. Exposure of the probe may be terminated at any time by withdrawing the probe from the flue wall and closing the port in the wall.

\section{PROBE TEMPERATURE CONTROL}

A block diagram of the overall probe configuration and control system is shown in FIg. 3. The thermocouple Is mounted along the top (downstream) surface of the probe. Although the bead will be exposed to fouling at this location, it is felt that by being cemented into a recess in the probe at this location a more representative value of average probe temperature will be obtained. Also, the thermocouple will not be exposed to the direct force of the flue gas stream. The thermocouple, which is attached to the outer surface of the test section, provides a signal. to the controller. The controller regulates an internal heater and air flow valve to maintain temperature. Actual temperature concrol is accomplished by a conventional PID controller (e.8. a Barber-Coleman Model 570 process controller). This unit measures probe temperature by means of the thermocouple, and computes an appropriate output signal to drive the control elements, an electric power control, and an air flow control valve. The power

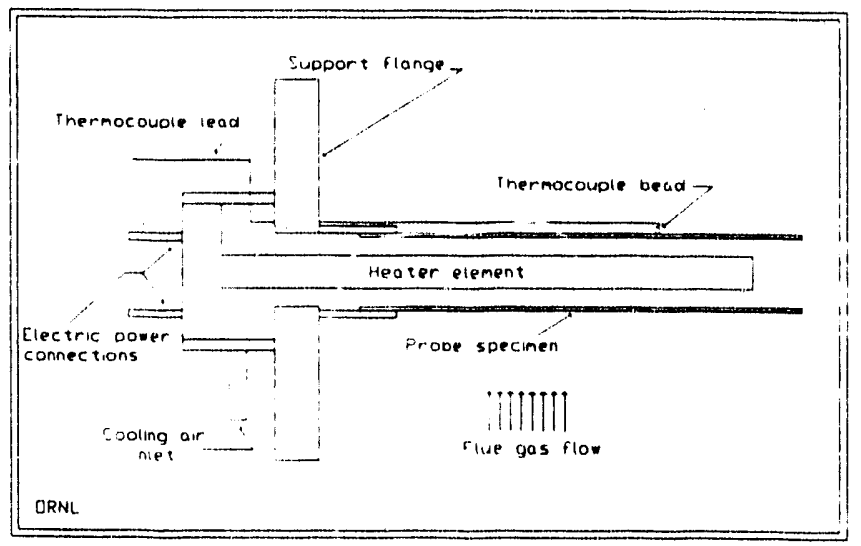

Figure 2. Corrosion probe detail.

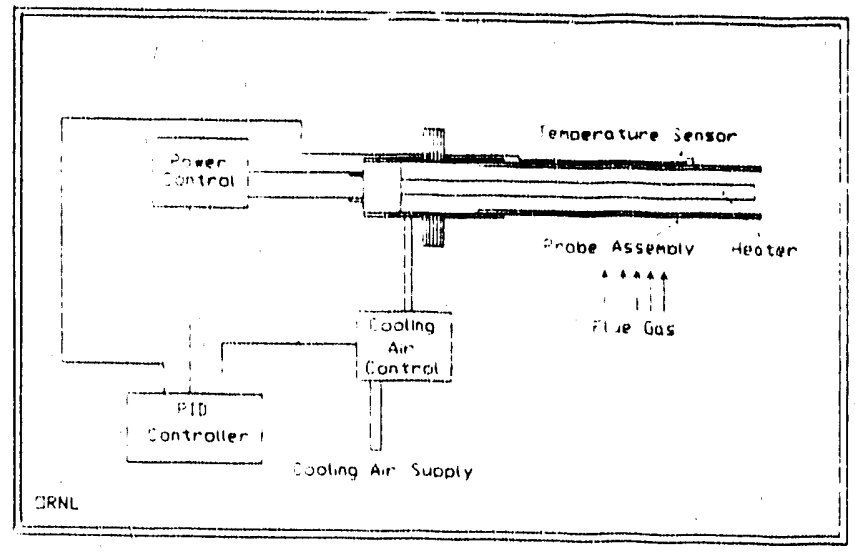
diagram.

Figure 3. Probe assembly/control system block

controller is a single-phase, $115-V$, phase-fired silicon controlled rectifier (SCR) unit. The cooling air flow control is a conventional proportional preumatic valve, which is driven by an $I / P$ (curient-to-pressure) converter. The output from the process controller is a standard 4. to 20-mA signal. The $12 \cdot \mathrm{mA}$ point is used as a c... rol "null" point. A signal greacer than 12 mA results in the heater being energized, and a signal below $12 \mathrm{~mA}$ results in actuation of the cooling air concrol valve. This configuration provides appropriate control with a minimum of components.

\section{HEAT TRANSFER CALCULATIONS}

The steady state effects of probe size, heater output, cooling air flow rate, and flue gas temperature and flow rate on the temperature of the probe were investigated by a computer model. The model calculates the thermal balance in the probe as affected by heat flow due to convection and radiation associated with the flue gas and walls, the heater output, and cooling air flow rate. The calculations were conducted for a SiC corrosion probe having the characteristics shown in Table 3, for flue gases having the characteristics shown in Tables 2 and 4, for a refractory furnace flue having the characteristics shown in Table 5 , and for cooling air having the characteristics shown in Table 6. Accurate temperature control requires balancing of the thermal. energy received by and transferred from the probe. The balance of thermal energy within the probe $\left(q_{s}\right)$ can be described in terms of the various components :

$$
q_{s}-q_{c g}+q_{r f}+q_{c h}+q_{r h}+q_{c a}
$$

where

\footnotetext{
$\mathrm{q}_{\mathrm{cg}}$ - convective heat transferred $20 /$ from the probe by the flue gases.

qrf - radiative heat transferred to/from the probe by the flue wall.

$q_{c h}$ - convective heat transferred to/from the probe by the heater,

$q_{r h}$ - radiative heat transferred to/from the prube by the heater.

$q_{c a}$ - convective heat transferred to/from the probe by cooling air.
} 
Table 3. Characteristics of S1C probe and heater used in heat transfer calculations

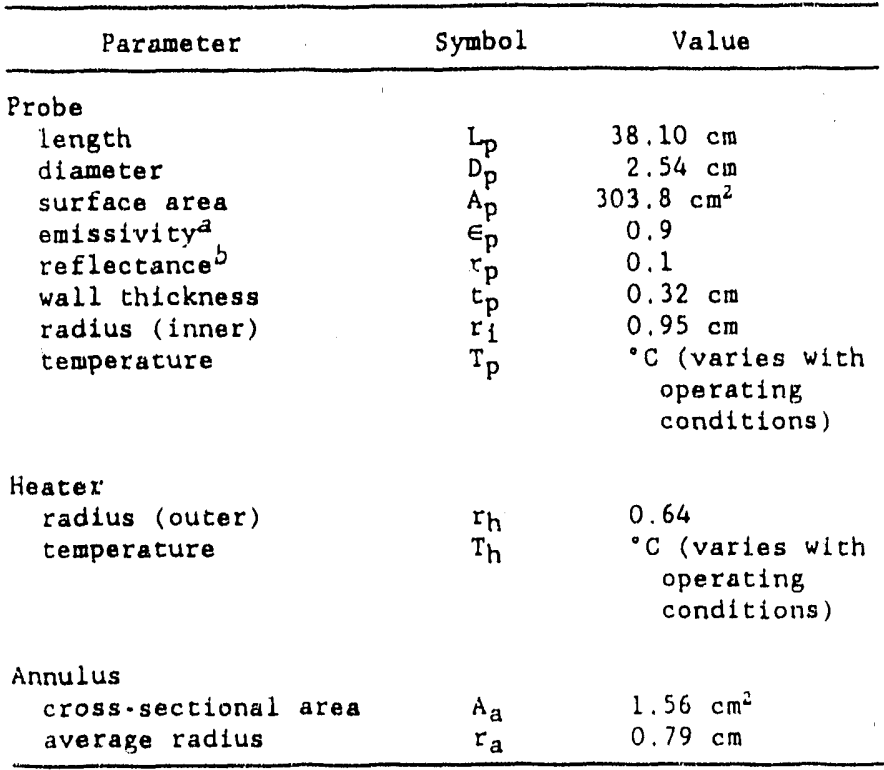

${ }^{a}$ Standard O1.1 Engtneered Materials Co.

Niagara Falls, New York (formerly Carborundum Resistant Materials Company).

$b_{p}-1 \cdot E_{p}$.

Table 4. Characterlstics of flue gases used in heat transfer calculations

\begin{tabular}{lcc}
\multicolumn{1}{c}{ Parameter } & Symbol & Value \\
\hline Viscosity & $\mu_{\mathrm{g}}$ & $0.05 \mathrm{mPa} \cdot \mathrm{s}$ \\
$\begin{array}{l}\text { Denslty } \\
\text { h1gh fire } \\
\text { low fire }\end{array}$ & $\rho_{\mathrm{gh}}$ & $0.26 \mathrm{~kg} / \mathrm{m}^{3}$ \\
Thermal conductivity & $\rho_{\mathrm{gl}}$ & $0.05 \mathrm{~kg} / \mathrm{m}^{3}$ \\
Mass flow rate & $\mathrm{k}_{\mathrm{g}}$ & $0.08 \mathrm{~mW} / \mathrm{m} \cdot \mathrm{K}$ \\
high fire & & \\
low fire & $\dot{\mathrm{m}}_{\mathrm{gh}}$ & $1.59 \mathrm{~kg} / \mathrm{s}$ \\
Velocity & $\dot{\mathrm{m}}_{\mathrm{gl}}$ & $0.32 \mathrm{~kg} / \mathrm{s}$ \\
high fire & & \\
low flre & $\mathrm{v}_{\mathrm{gh}}$ & $414.1 \mathrm{~cm} / \mathrm{s}$ \\
Reynolds number & $\mathrm{v}_{\mathrm{gl}}$ & $82.8 \mathrm{~cm} / \mathrm{s}$ \\
\hline
\end{tabular}

The convective heat flow between the probe and the flue gas is given by Newton's Law of Cooling:

$$
a_{c g}=\left(T_{g}-T_{p}\right) h_{c} A_{p} \text {, }
$$

where

$$
\begin{aligned}
& T_{g} \text { - cemperature of the flue gases, } \\
& T_{p} \text { - temperature of the probe, } \\
& h_{c} \text { - convective heat transfer coeffletent, } \\
& A_{p} \text { - surface area of the probe. }
\end{aligned}
$$

Table 5. Characteristics of flue used in heat transfer calculations

\begin{tabular}{lcc}
\hline \multicolumn{1}{c}{ Parameter } & Symbol & Value \\
\hline Cross-sectional area & $A_{f}$ & $15,000 \mathrm{~cm}^{2}$ \\
Emissivity & $E_{f w}$ & 0.8 \\
Reflectance & & \\
Geometric view factors $c$ & $F_{f w}$ & 0.2 \\
& $F_{33}$ & 1 \\
& $F_{32}$ & 0 \\
\hline
\end{tabular}

Estimated.

$b_{r_{f w}}-1$. E Ew (for solld body).

${ }^{c} \mathrm{~F}_{23}$ - View factor from probe to flue wall.

\begin{tabular}{|c|c|c|}
\hline Parameter & Symbol & Value \\
\hline$\overline{\text { Dens1ty }}$ & $\rho_{A}$ & $0.32 \mathrm{~kg} / \mathrm{m}^{3}$ \\
\hline Thermal conductivitya & $k_{A}$ & $0.08 \mathrm{~mW} / \mathrm{m} \cdot \mathrm{K}$ \\
\hline Viscosity ${ }^{a}$ & $\mu_{\mathrm{A}}$ & $0.05 \mathrm{mPa} \cdot \mathrm{s}$ \\
\hline Specific heata & $c_{p A}$ & $1222.6 \mathrm{~J} / \mathrm{kg} \cdot \mathrm{K}$ \\
\hline Volume flow rate & $Q_{A}$ & $102413 \mathrm{~cm}^{3} / \mathrm{s}$ \\
\hline $\begin{array}{l}\text { Cooling air inlet } \\
\text { temperature }\end{array}$ & $\mathrm{T}_{\text {IN }}$ & $27^{\circ} \mathrm{F}$ \\
\hline
\end{tabular}

$\mathrm{F}_{33}$ - View factor from flue wall to flue wall.

$\mathrm{F}_{32}$ - View factor from flue wall to probe.

Table 6. Characterlstics of cooling air used in hear transfer calculations

W. Eshbach, ed, John Wiley and Sons, New York, p. 650

The convective heat transfer coefflcient is given by H1lpert (1933):

$$
h_{c}=\frac{k_{g} \cdot C \cdot R_{e g}^{n}}{D_{p}}
$$

where all terms excopt $C$ and $n$ are identifled in Tables 3 and 4 . The values of $C$ and $n$ depend on the value of the Reynolds number $\left(R_{e g}\right)$, and were obtained from the following table (Hllpert, 1933).

\begin{tabular}{lcc}
\multicolumn{1}{c}{$R_{\text {eg }}$} & $\mathrm{C}$ & $\mathrm{D}$ \\
$0.4-4$ & & \\
4.40 & 0.891 & 0.330 \\
$40-4000$ & 0.821 & 0.385 \\
$4000-40,000$ & 0.615 & 0.466 \\
$40,000-400,000$ & 0.174 & 0.618 \\
& 0.0239 & 0.805
\end{tabular}

The total radiatlve heat flow between the probe and the flue wall can be shown to be

$$
q_{r f}=\frac{E_{p}}{r_{p}}\left(R_{2}-0 \cdot T_{p}^{4}\right) A_{p}
$$

where o 18 the stekan-Boltzman constant $\left(4.805 \mathrm{E}-13 \mathrm{Btu} / \mathrm{ft}^{2} \cdot \mathrm{s} \cdot \mathrm{R}^{4}\right)$ and new terns except $R_{2}$ are identified in Table 3 . The tern $R_{2}$, the radiosity, 18 given by 


$$
R_{2}-\frac{E_{p} \cdot \sigma \cdot T_{p}{ }^{4}\left(1-r_{f w} \cdot F_{33}\right)+r_{p} \cdot F_{23} \cdot E_{f w} \cdot \sigma \cdot T_{g}{ }^{4}}{1-r_{f w} \cdot F_{33}-r_{p}{ }^{2} \cdot F_{23} \cdot F_{32}}
$$

where new terms are identifled in Tables 3 and 5 . The total heat transfer between the probe and 1 ts surroundings is obtalned by combining the convective and radiative contributions

$$
q_{t}-q_{c g}+q_{r f} .
$$

Table 2 shows that the flue gas temperature varies between 750 and $1300^{\circ} \mathrm{C}$. Either heating or cooling is required to maintain the probe temperature within this range. When the flue gas temperature is below the desired probe temperature, heat is added to the specimen from the internal heater. Initially, electric heating is being employed, although the heat may be provided either electrically or by gas combustion. The electric heater is essentially completely enclosed by the specimen; therefore, in the steady-state condition, the heat input to the probe by convection and radiation is equal to heater input power. Since our heater can provide about $1.6 \mathrm{~kW}$.

$$
q_{h}=q_{c h}+q_{r h}-1.6 \mathrm{~kW}
$$

When the flue gas temperature is above the desired probe temperature, excess heat must be removed from the probe. This is accomplished by flowing a stream of cooling air through the bore of the probe. This component $\left(q_{c a}\right)$ of heat transfer can be obtalned from the following relation:

$$
\begin{aligned}
& q_{c a}-\rho_{A} Q_{A} C_{P A} \\
& {\left[\left(\frac{h_{1} r_{h} T_{h}+h_{2} r_{1} T_{p}}{h_{1} r_{h}+h_{2} r_{1}}\right)\left(1-e^{-\left\langle h_{1} r_{h}+h_{2} r_{1}\right\rangle} \frac{2 \pi L_{p}}{\rho_{A} Q_{A} c_{p A}}\right)\right]} \\
& \text { - } \rho_{A} Q_{A} C_{P A} T_{I N}
\end{aligned}
$$

where

$$
\begin{aligned}
& h_{1} \text { - convective heat transfer coefficlent } \\
& \text { between the hester and the cooling air as a } \\
& \text { function of cooling air flow rate. } \\
& h_{2} \text { - convective heat transfer coefficlent between } \\
& \text { the inner surface of the probe and the cooling } \\
& \text { air as a function of cooling air flow rate. }
\end{aligned}
$$

The term in brackets in Eq. (8) was developed for design analysis of probe performance as a function of cooling ale flow rate, $Q_{A}$, heat tranafer film coefficients, $h_{1}$ and $h_{2}$, and the location within the probe, $h_{p}$. Tho term 1s equivalent to the actual temperature of the cooling ais at the exit of the probe, a quantity that could be mensured during probe operotion with sultably placed therrocouple.

Uaing Eq. (6), the quantlty qt was calculated for the temperature range 750 to $1300^{\circ} \mathrm{C}$. Figure 4 show: that $q_{t}$, the anount of heat to be added or removed fron the probe, increases with increasing difforence between $I_{g}$ and $T_{p}$. Thle flgure defines the operating regine of the probe if sufficient heating and cooling capacity are avaliable to anintain the dealred probe temperature. Because the avallable eloctrical heater can provide only

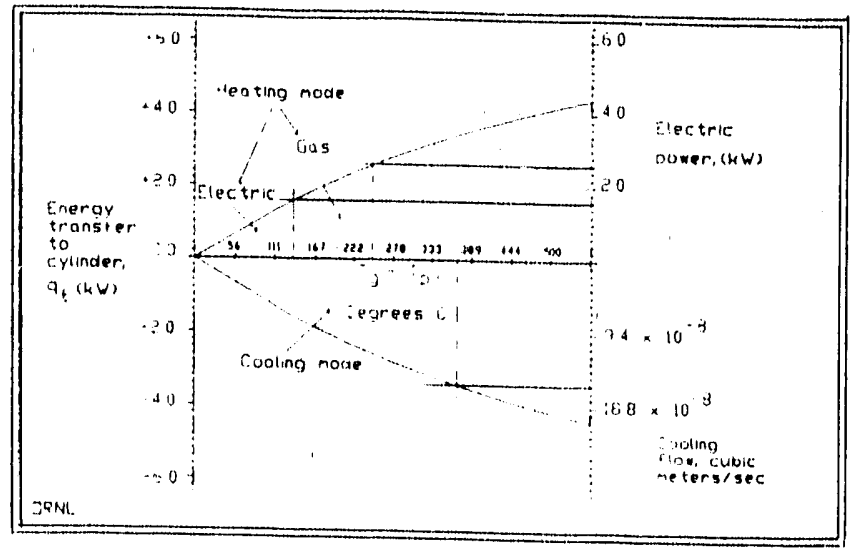

Figure 4. Controlled temperature corrosion probe operating regime.

$1.6 \mathrm{~kW}$ of heal, the probe can be maintained at a temperature $-125^{\circ} \mathrm{C}$ above $\mathrm{T} g$. Better control can be obtained if conling is required. The cooling capacity obtained from Eq. (8) allows the probe to operate at a temperature $-375^{\circ} \mathrm{C}$ below $\mathrm{T}_{\mathrm{g}}$.

\section{SUMMARY}

A need to evaluate candidate waste heac recovery materials under essentially constant temperature conditions has been identifled. Appropriate modeling and design calculations demonstrate the feasibility of constructing a controlled-temperature corrosion probe. These calculations also indicate that sufficient energy may not be avallable frow existing olectric heating elements to control probe temperature. While the initial configuration utilizes such an element provisions are being made to incorporate a gas burier in future designs to permit a broader operating regime in the heating mode.

A corrosion probe is now being fabricated acicording to the conceptual design described herein. Fabrication of this probe is intended to reveal assembly problems and to provide a prototype for labord ory testing, which will be conducted in a simulated furnace flue using natural gas combustion products as the flue gases. The responsiveness of the heater and cooling air to vartous flue gan temperatures will be determined, and control systen performance will be avaluated.

\section{REFERENCES}

Foderer, J. I., and Jones, P, J., 1985, Oxtdation/Corrosten of Kotallic and Ceramic Moterials in an Aluninum Remelt Furnace, ORNL/TM-9741, Oak RIdge National Laboratory, Oak Ridge, Tennersee.

Foderor, J. I., Tlogs, T. N., Kotchlck, D. M., and Potrak, D., 1985, Analysta of Candidare Stilicen Carbide Recuzeratior Matorials Exposed te Industrial Furnace Enviroments, ORNL/T74-9677, Oak RIdge National Laboratory, Oak RIdge, Tennemsee.

HIlpert, R., "Warmabgabe von geholizen Drahten und Rohron," Eersch. Geblate Ingenteury. , Vol. 4, 1933 , p. 220 .

Hoffan, L. C., Willlams, H. W., and Krenger, A. H., 1987, Eluldtzed Bed Waste Hear Recovery System Proeram

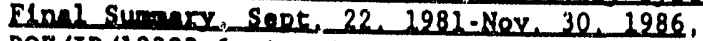
DOE/ID/12303-6, Aerojet Energy Converaion Coupany, Rancho Cordova, Callfornia.

Marner, W. J., and Hanslee, S. P., 1985, "A Survey of Gas-side Fouling Measuring Dovices," Preceedines of the 
1985 Expositton and Sympostum on Industrial Heat Exchanger Technology, A, J. Hayes et al., ed., American Soclety for Metals, pp. 209-226.

Marner, W. J., and MacDavid, K. S., 1987, fyelopinent of a Gas-S1de Fouling Measuring Device, DOE/I:.12138-7,

Jet Propulsion Laboratory, California Instituta of Technology, Pasadena, California.
Russoll, A, D., Sueltzer, C, E., and Ward, M. E., 1983, Wagte Heat Recuperation for Aluminum Furnaces, GRI-81/0160, Solar Turbines, Inc., San Diego, Callfornia.

Weber, G. W., and Tennery, V. J, , 1979, Macerdads Analyses of Ceramics for Gilass Furnace Recuperators, ORNL/TM.6970, Oak Ridge National Laboratory, Dak Ridge, Tennessee. 
ORNL -6630

INTERNAL DISTRIBUTION

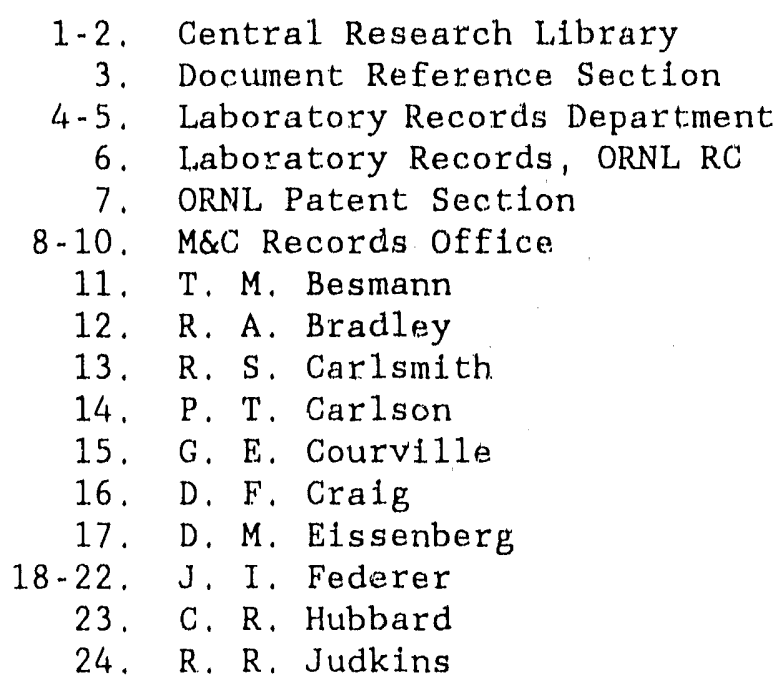

\author{
25. J, R, Keiser \\ 26. C. M. Malone \\ 27-31. J. A. McEvers \\ 32. A. J. Moorhead \\ 33. P. L, Rittenhouse \\ 34. G, M. Slaughter \\ 35. D. P. Stinton \\ 36. V. J. Tennery \\ 37. D. F, Wilson \\ 38. A. D. Brails ford (Consultant) \\ 39. H. D. Brody (Consultant) \\ 40. D. P. Pope (Consultant) \\ 41. M. L. Savitz (Consultant) \\ 42. E. R. Thompson (Consultant) \\ 43. J. B. Wachtman (Consultant)
}

\section{EXTERNAL DISTRIBUTION}

44. ADVANCED REFRACTORY TECHNOLOGIES, INC., 699 Hertel Avenue, Buffalo, NY 14207

P. T. B. Shaffer

45. AIRESEARCH MANUFACTURING COMPANY, 2525 W. 190th Street, Torrance, CA 90509

D. M. Kotchick

46. BABCOCK AND WILCOX, R\&D Division, 1562 Beeson Street, Alliance, OH 4.4601

$$
\text { C. L. DeBellis }
$$

47-48. BABCOCK AND WILCOX, P.O. Box 11165, Lynchburg, VA 24505

E. A. Barringer
D. L. Hindman

THE CARBORUNDUM COMPANY, P.O. Box 1054, Niagara Falls, NY 14302

$$
\text { IV. C. Kerr }
$$


50. CONSOLIDATED NATURAL GAS, 11001 Cedar Avenue, Cleveland, oH 44106

J. Bjerklie

51. COORS PORCELAIN COMPANY, 600 Ninth street, Golden, CO 80501.

R. Kleiner

52-53. GAS RESEARCH INSTITUTE, $8600 \mathrm{~W}$. Bryn Mawr Ave,, Thicago, IL 60631

S. Freedman

M. A. Lukasiewicz

54. IDAHO NATIONAL ENGINEERING LABORATORY, P.0, Box 1625, Idaho Fa11s, ID 83415

B. W. Brown

55. NORTON COMPANY, Worcester, MA 01606

B. D. Foster

56. PAR ENTERPRISE, INC, 12601 Clifton Hunt Lane, Clifton, VA 22024

W. J. Rebe11o

57. PENNSYLVANIA STATE UNIVERSITY, 201 Steldle Bullding, Untversity Park, PA 16801

R. E. Tressler

58. POWER GENERATION CONSULTANTS, 1261 Post House Lane, Media, PA 19063

M. DeCorso

59. SOLAR TURBINES INCORPORATED, P.O. Box 85376, San Diego, CA 92138-5376

M. Van Roode

60. STONE \& WEBSTER ENGINEERING CORPORATION, 245 Summer street, Boston, MA 02107

R. A. Rosenberg

61. UNIVERSITY OF ILLINOIS AT CHICAGO, P.O. Box 4348, Chicago, IL 60680 M. J. McNallan

62. UNIVERSITY OF TENNESSEE SPACE INSTITUTE, MS 3, Tul.1ahoma, TN 37388

W. H. Boss

63. U.S. DOE, IDAHO OPERATIONS OFFICE, 550 Second Street, Idaho Falls, ID 83401

G. R. Peterson 
64-65. U.S. DOE, OAK RIDGE OPERATIONS OFFICE, Oak RIdge, TN 37831.

M. J, Rohr

Assistant Manager for Energy Research and Development

66-68. U.S, DOE, OFFICE OF INDUSTRIAL TECHNOIOGIES, 1000 Independence Avenue, forrestal Bullding, Washington, DC 20585

J. Eustis

W. P. Parks, Jr.

S. L. Richien

69-78. U.S. DOE, OFFICE OF SCIENTIFIC AND TECHNICAL INFORMATION, P. O, BOX 62, Oak Ridge, 'TN 37831

For distribution by microfiche as shown in DOE/OSTI-4500, Distribution Category UC-310 [Industria1 Programs (Genera1)]. 

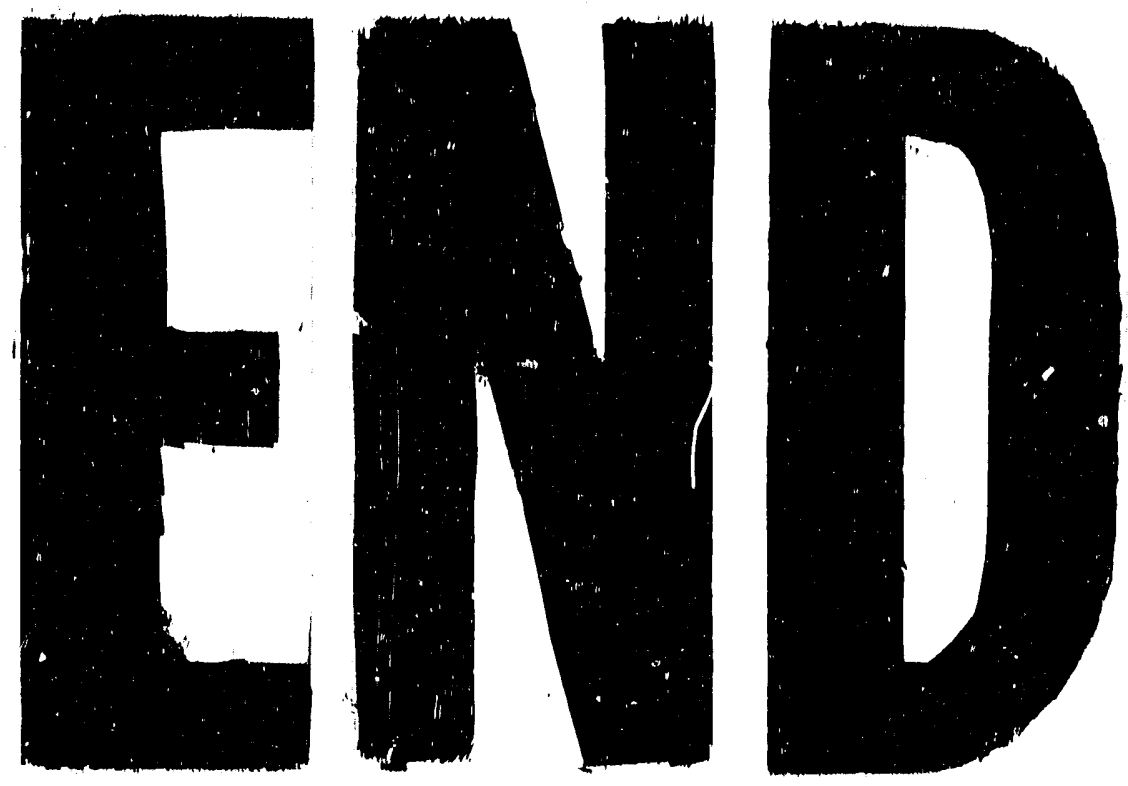

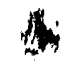
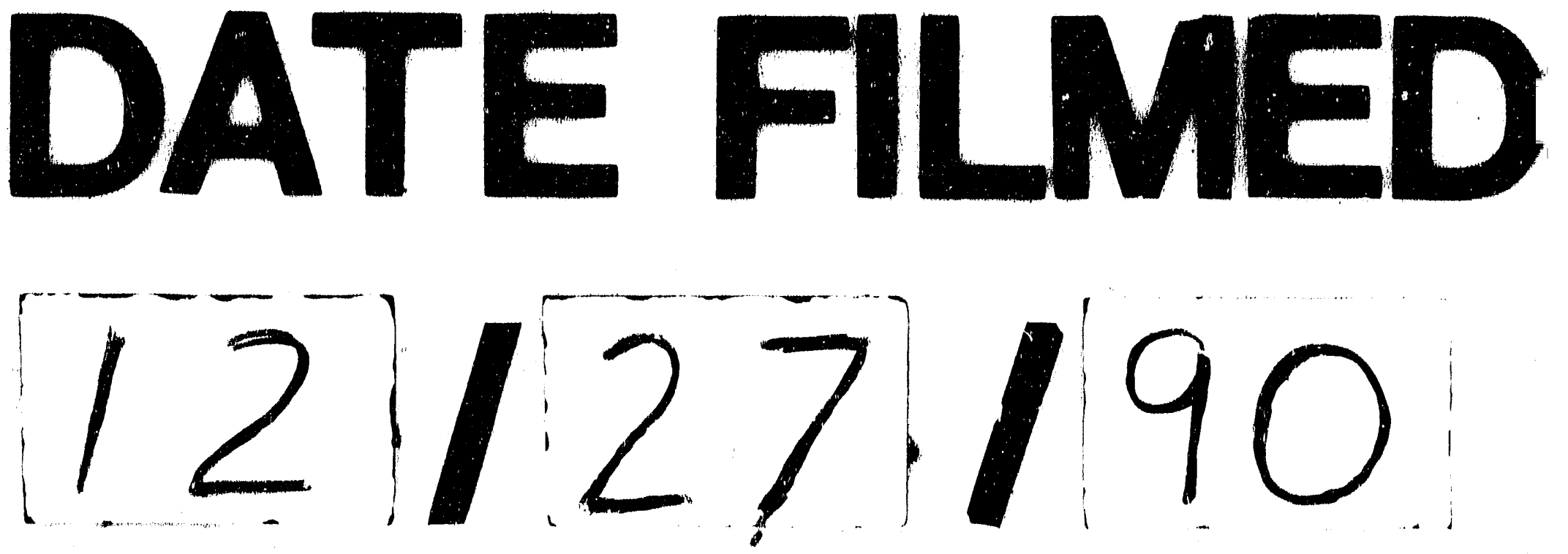
